\title{
WELDING URANIUM WITH A MULTIKILOWATT, CONTINUOUS-WAVE, CARBON DIOXIDE \\ LASER WELDER
}

P. W. Turner

A. B. Townsend

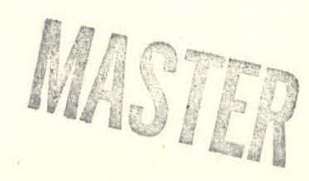

\section{OAK RIDGE Y-12 PLANT}

OAK RIDGE. TENNESSヒヒ

prepared for the U.S. ENERGY RESEARCH AND DEVELOPMENT ADMINISTRATION under U.S. GOVERNMENT Contract W-7405 eng 26 


\section{DISCLAIMER}

This report was prepared as an account of work sponsored by an agency of the United States Government. Neither the United States Government nor any agency Thereof, nor any of their employees, makes any warranty, express or implied, or assumes any legal liability or responsibility for the accuracy, completeness, or usefulness of any information, apparatus, product, or process disclosed, or represents that its use would not infringe privately owned rights. Reference herein to any specific commercial product, process, or service by trade name, trademark, manufacturer, or otherwise does not necessarily constitute or imply its endorsement, recommendation, or favoring by the United States Government or any agency thereof. The views and opinions of authors expressed herein do not necessarily state or reflect those of the United States Government or any agency thereof. 


\section{DISCLAIMER}

Portions of this document may be illegible in electronic image products. Images are produced from the best available original document. 
Reference to a company or product name does not imply approval or recommendation of the product by Union Carbide Corporation or the U.S. Energy Research and Development Administration to the exclusion of others that may meet specifications.

Printed in the United States of America. Available from National Technical Information Service

U.S. Department of Commerce

5285 Port Royal Road, Springfield, Virginia 22161

Price: Printed Copy $\$ 3.50$; Microfiche $\$ 3.00$

This report was prepared as an account of work sponsored by the United States Government. Neither the United States nor the Energy Research and Development Administration, nor any of their employees, nor any of their contractors, subcontractors, or their employees, makes any warranty, express or implied, or assumes any legal liability or responsibility for the accuracy, completeness or usefulness of any information, apparatus, product or process disclosed, or represents that its use would not infringe privately owned rights. 
Date of Issue: June 15, 1977

Report Number: Y-2079

Distribution Category: UC-38

WELDING URANIUM WITH A MULTIKILOWATT, CONTINUOUȘ-WAVE, CARBON DIOXIDE LASER WELDER

\author{
P. W. Turner(a) \\ A. B. Townsend \\ Metallurgical Development Department \\ Y-12 Development Division
}

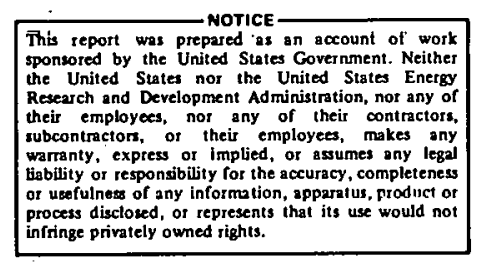

Oak Ridge Y-12 Plant

P. O. Box Y, Oak Ridge, Tennessee 37830

Prepared for the US Energy Research and Development Administration

Under US Government Contract W-7405-eng-36

(a) Formerly an employee in the Metallurgical Development Department Welding Laboratory. 


\begin{abstract}
A 15-kilowatt, continuous-wave, carbon dioxide laser was contracted to make partial-penetration welds in 6.35 and 12.7 -mm-thick wrought depleted uranium plates. Welding power and speed ranged from 2.3 to 12.9 kilowatts and from 21 to 127 millimeters per second, respectively. Results show that depth-to-width ratios of at least unity are feasible. The overall characteristics of the process indicate it can produce welds resembling those made by the electron-beam welding process.
\end{abstract}




\section{CONTENTS}

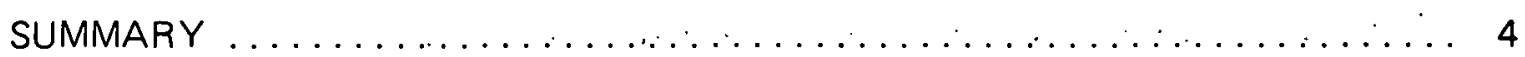

INTRODUCTION $\ldots \ldots \ldots \ldots \ldots \ldots \ldots \ldots \ldots \ldots \ldots \ldots \ldots \ldots . . . \ldots \ldots \ldots \ldots \ldots$

WELDING URANIUM W.ITH.A MULTIKILOWATT, CONTINUOUS-WAVE, CARBON DIOXIDE LASER WELDER .............. 6

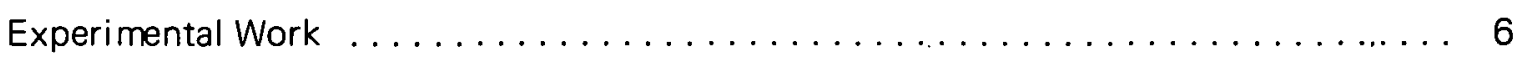

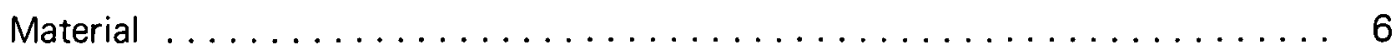

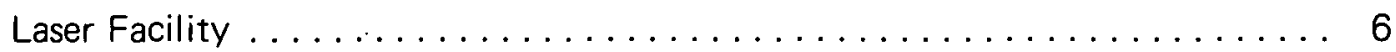

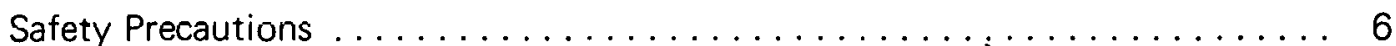

Welding Variables . . . . . . . . . . . . . . . . . . . . . 7

Setup and Preparation for Welding Uranium $\ldots \ldots \ldots \ldots \ldots \ldots \ldots$

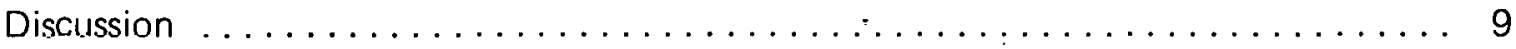




\section{SUMMARY}

A 15-kilowatt, continuous-wave, carbon dioxide laser was contracted to make partial-penetration welds in 6.35 and $12.7-\mathrm{mm}$-thick wrought depleted uranium plates. Welding power and speed ranged from 2.3 to 12.9 kilowatts and from 21 to 127 millimeters per second, respectively. Results show that depth-to-width ratios of at least unity are feasible. The overall characteristics of the process indicate it can produce welds resembling those made by the electron-beam welding process. 


\section{INTRODUCTION}

High-power, continuous-wave, $\mathrm{CO}_{2}$ laser (HPL) facilities have demonstrated much of the capability of the electron-beam process. Features that make an HPL facility relatively attractive, in this respect, are as follows: (1) the high-power density of the laser beam makes it applicable to welding, cutting, or heating a variety of materials; (2) work is not enclosed in a vacuum chamber; thus, the productivity and duty cycle exceeds that of the electron-beam welder; (3) visibility is excellent during welding (the $\mathrm{CO}_{2}$ laser is enclosed in a Plexiglas cage); (4) since electrical circuits and clamps to the work and alignment fixtures are not needed, both metals and nonmetals can be thermally processed and fixtured without hard, electrically conductive tooling that would tend to mar, scratch, or arc the work surfaces; (5) the laser beam is insensitive to magnetism; (6) a single laser facility can service several widely separated (typically, hundreds of feet from the laser) welding, cutting, or material processing stations on a time-sharing basis to maximize its duty cycle and general utility; (7) the HPL beam can be directed a considerable distance to do useful thermal work at locations inaccessible to conventional heat sources (also it can be directed into assembly dry rooms, hot cells, environmental rooms, and the like, which are not conveniently accessible to personnel).

To evaluate the potential of the multikilowatt laser, Purchase Order $73 Y-88277 \mathrm{~V}$ was initiated to weld uranium specimens on the HPL facility at the AVCO Everett Research Laboratory. Uranium specimens were selected for evaluating the HPL facilities so that results could be compared to electron-beam technology for joining uranium at the Oak Ridge $Y-12$ Plant. (b)

A survey of the manufacturers of multikilowatt laser. welding equipment revealed that uranium had not been welded by the $\mathrm{CO}_{2}$, continuous-wave, high-power laser process. Also, only one of the facilities had a source material license for receiving and welding large amounts of depleted uranium.

(b) Operated by the Union Carbide-Corporation's Nuclear Division for the US Energy Research and Development Administration. 


\section{WELDING URANIUM WITH A MULTIKILOWATT, CONTINUOUS-WAVE, CARBON DIOXIDE LASER WELDER}

\section{EXPERIMENTAL WORK}

\section{Material}

Wrought, depleted uranium plates, ,totaling $44.16 \mathrm{~kg}$, were machined to form square edges for welding. Half the plates were $12.7 \mathrm{~mm}$ in thickness, the remainder were $6.35 \mathrm{~mm}$ in thickness. The length and width of the plates were 76.2 and $50.8 \mathrm{~mm}$, respectively. The level of impurity elements in the depleted uranium was less than 600 ppm by weight, with an iron content of less than 100 ppm.

\section{Laser Facility}

Figure 1 gives, schematically, a diagram of the 15-kilowatt laser facility. The optical system directs the beam to two work stations. Only the illustrated F/7 Station was used during this program. The electrical-discharge laser for this facility is located within the vacuum chamber. The laser cavity is shown, schematically, in Figure 2. This type of cavity (referred to as an "unstable oscillator")(c) transfers a hollow beam at all locations except at the focal point. The lasing $\mathrm{CO}_{2} / \mathrm{N}_{2}$ gas mixture is ionized by an electron-beam gun. A closed system of blowers and heat exchangers forms a wind tunnel and removes heat from the lasing cavity.

The divergent beam emerges from an aerodynamic window designed to prevent air from entering the vacuum chamber. The first water-cooled copper mirror (Figure 1) collimates the beam; the next three turning mirrors direct the collimated beam to the Casseyl diu $F / 7$ telescope shown, schematlcally, in Figure 3. The focal point is about seven diamctcrs from the large, concave mirrior. In Figure 1, the beam is lucused to weld in the flat position on the work table which translates the workpiece beneath the beam.

Operators of the HPL facility report that $30 \%$ of the power is lost from lhe bedill alter it emerges through a beamchopper located between the aerodynamic window and the collimating mirror.

\section{Safety Precautions}

The $\mathrm{CO}_{2}$ laser beam (wavelength, $10.6 \mu \mathrm{m}$ ) can be safely contained in a Plexiglas enclosure. Interlocks prevent operation of the laser while the door to the work area is open. Warning

(c). Siegman, A. E.; "Unstable Optical Resonators", Proceedings of the IEEE, 53, pp 277 - 287; March 1965. 


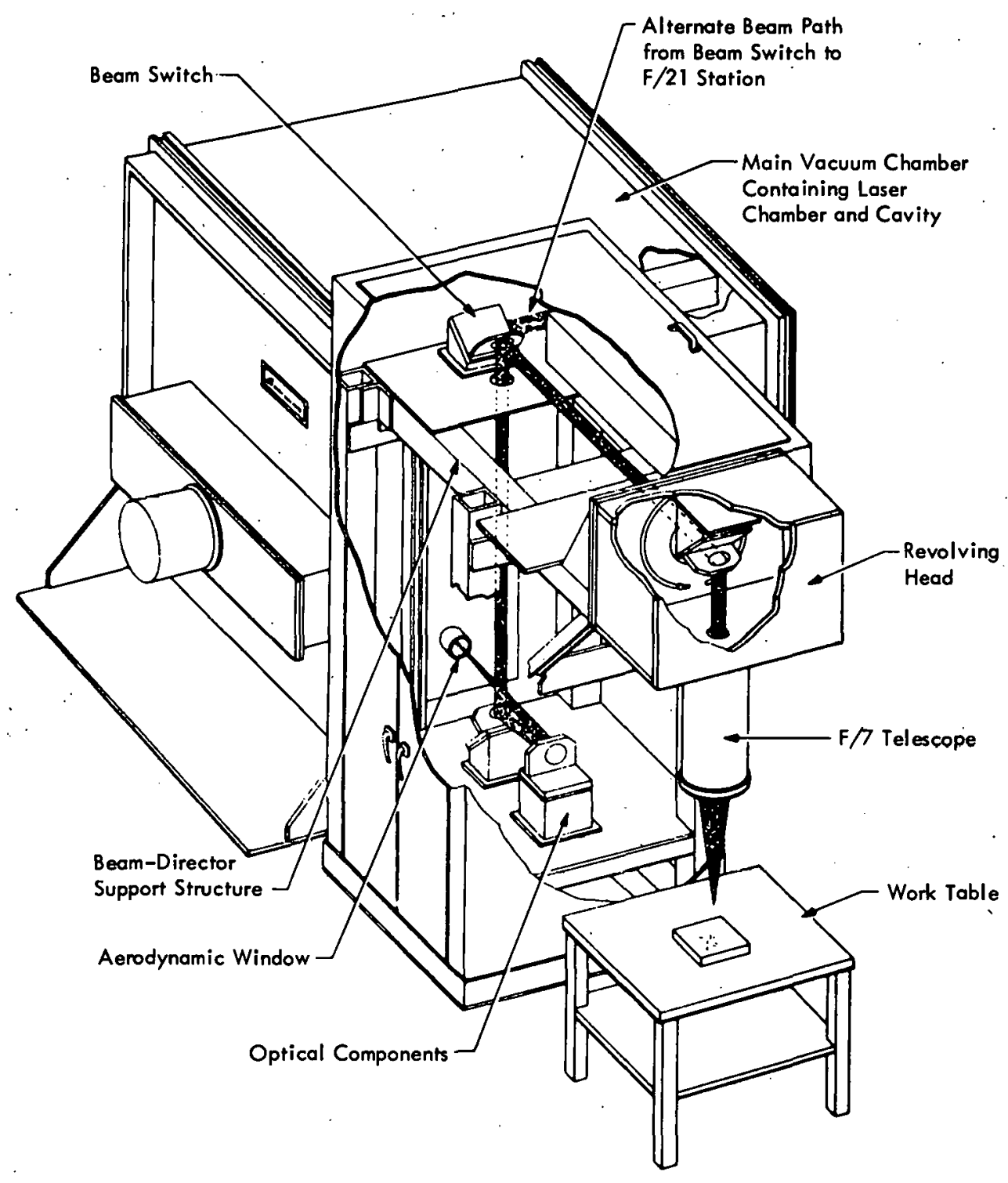

Figure 1. CONTINUQUS-WAVE, CARBON DIOXIDE' LASER WELDER, RATED AT 15 KILOWATTS. (Serving the F/7 Station)

lights and horns indicate when the laser station is active. It is the responsibility of the operator to assure that personnel are not within the transparent plastic enclosure during the time the beam is activated. Protection against electrical, noise, and radiation hazards meets standards of the Occupational Safety and Health Administration (OSHA).

\section{Welding Variables}

Laser welding variables, relating to thermal conditions, are: power, focal length, and welding speed. It is apparent that the number of operating variables is significantly less than the number the operator must handle in operating most other joining processes. 
Power selections ranged from 2.3 to $12.9 \mathrm{~kW}$, and the speed of welding was varied from 21 to $127 \mathrm{~mm} / \mathrm{s}$. These parameters were set on a 10-turn potentiometer (the dials were not calibrated directly). The ability to reset the values had an estimated $10 \%$ error. A limited amount of welding with the focal point below the surface resulted in erratic penetration. This mode was discontinued, but may prove to be a useful variable with more experimental effort.

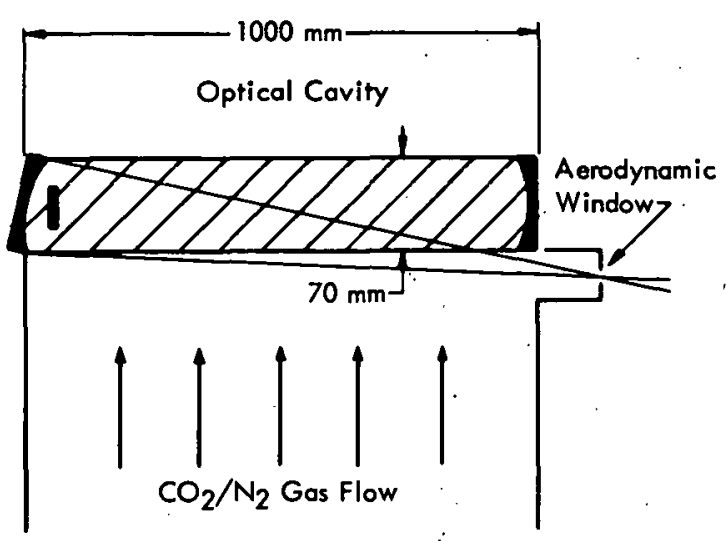

Figure 3. LASER CAVITY.

\section{Setup and Preparation for Welding Uranium}

Uranium plates were chemically etched to remove oxide within two to three hours before the start of the welding period. Plates were etched in warm nitric acid, rinsed with water,

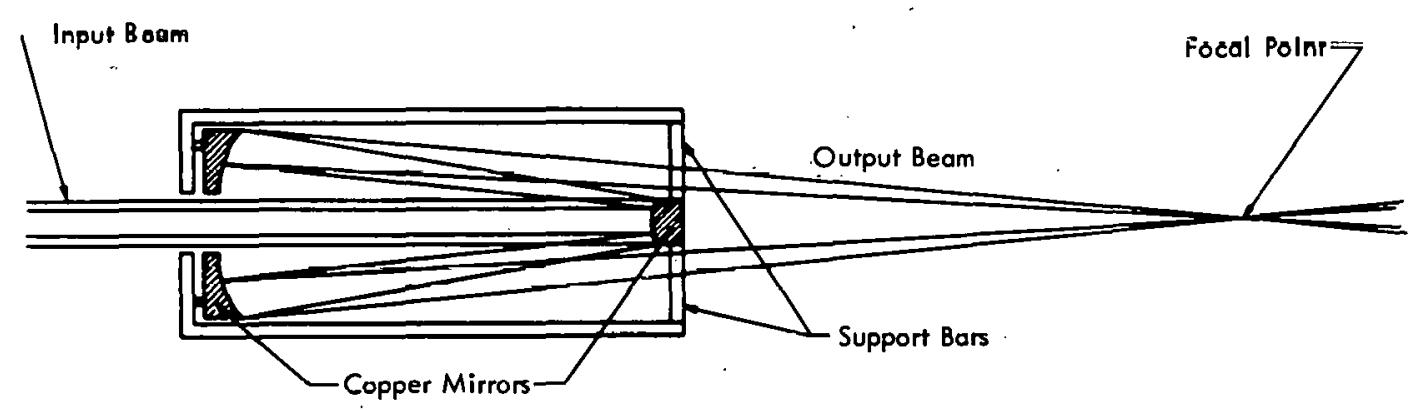

Figure 3. CASSEGRAIN F/7 WELDING TELESCOPE ROTATED TO THE HORIŻONTÁL POSITION.

and dried with alcohol. All steps in the welding setup were awkward because welding had to be done in a special, partially evacuated containment vessel designed to prevent the general area from being contaminated with uranium. This enclosure and the setups and tooling for welding in the flat and horizontal positions are shown, schematically, in Figures 4 and 5 . A photographic view of the enclosure oriented for welding in the flat position can be seen in Figure 6.

The work base is adjustable, vertically, to provide for variation in the telescope-to-work distance. Also, gas shielding is required to prevent oxidation of the reactive metals and to remove a plume of ionized metal vapor that forms and interferes with the laser beam at a high welding power. A Size 6 gas lens, shown schematically in Figure 7, directed 94 liters/min of helium over the weld zone. A backing gas was not used. A trailing gas was also not employed except for shielding some of the welds requiring high thermal inputs.

Figure 8 provides a view through one of the ports of the uranium containment vessel. It reveals the aluminum fixture on which plates were aligned and the gas-shielding device in position for welding. 


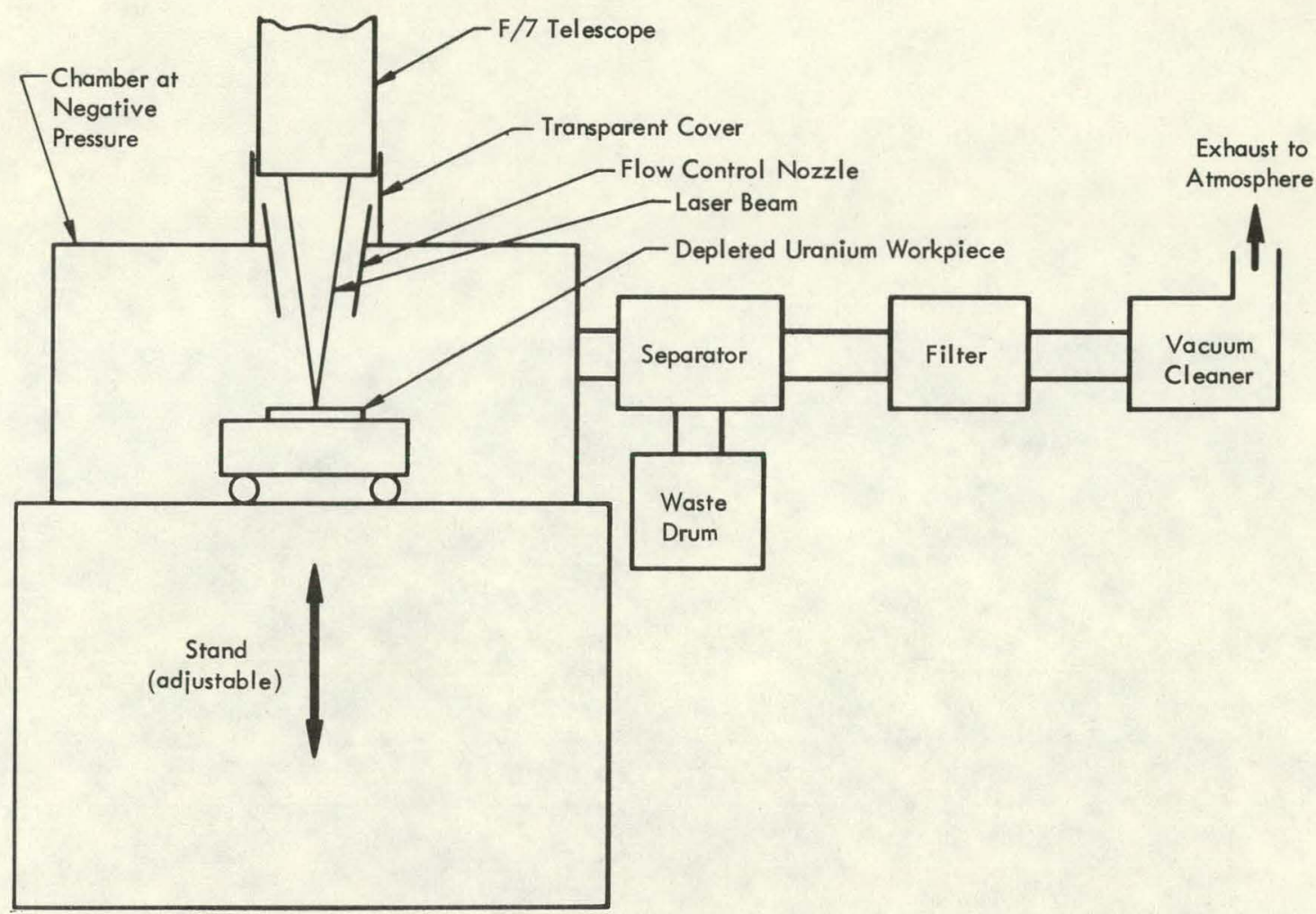

Figure 4. SETUP FOR LASER WELDING DEPLETED URANIUM IN THE FLAT POSITION. (System is Enclosed by Plexiglas Walls)

\section{DISCUSSION}

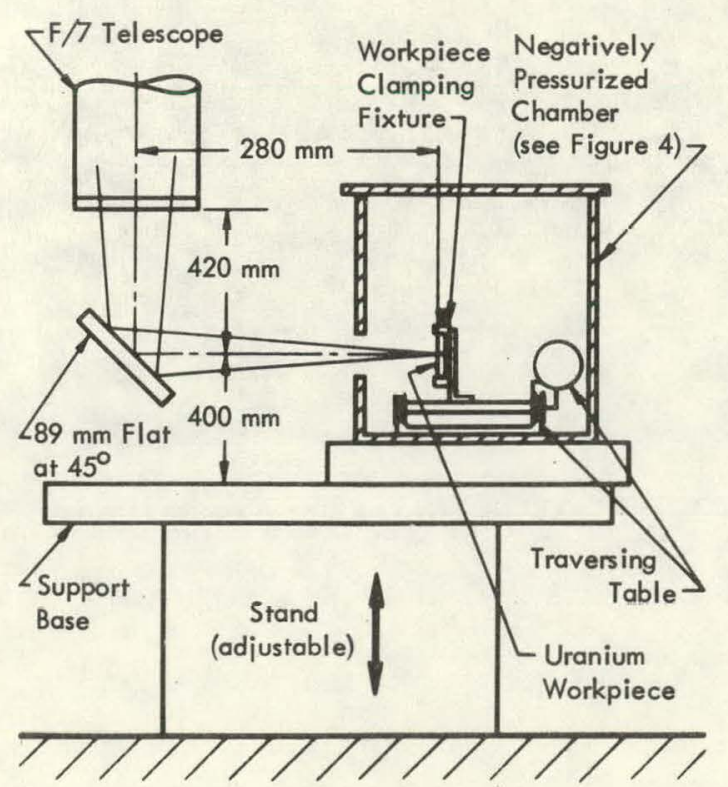

Figure 5. SETUP FOR LASER WELDING DEPLETED IURANIUM IN THF HORIZONTAL POSITION.
Parameters were developed for making 50 and $70 \%$ penetration welds in 6.35 -mm-thick uranium plates. Length of the welds was $76.2 \mathrm{~mm}$. Welds were made on AISI 304 steel and on uranium to determine what changes in the established parameters for steel should be made when welding uranium. Comparison of the macrographs in Figures 9 and 10 indicate the effect of the focal length on the shape of the fusion zone of stainless steel welds. The same parameters on uranium produced about the same penetration, but with larger fusion zones.

The 12.7-mm-thick uranium plates were welded in the flat and horizontal positions; the 0.35 -mm-thick plates were welded in the flat position only. The target penetration was $75 \%$. 


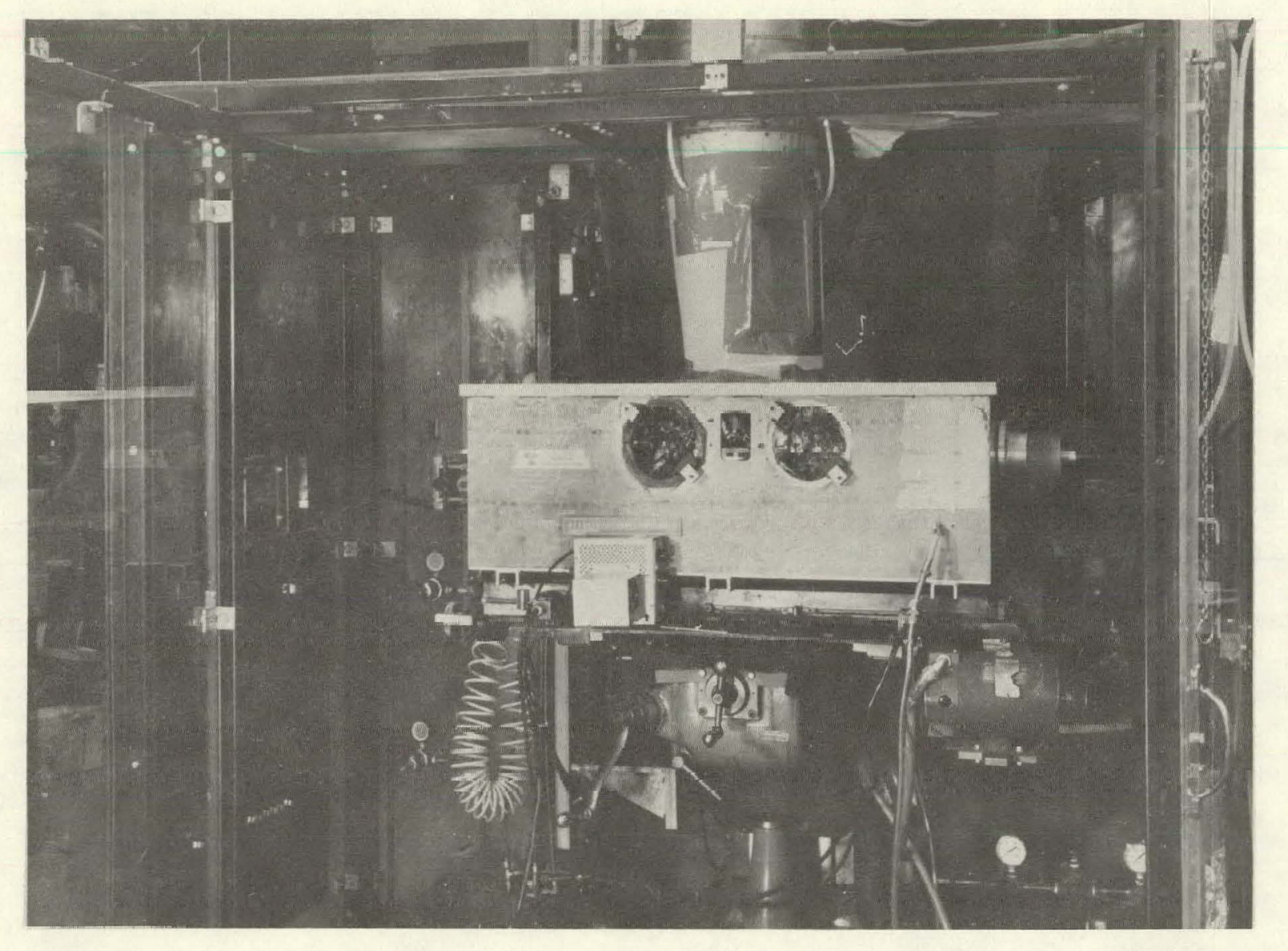

Figure 6. VIEW OF THE CONTAINMENT VESSEL FOR LASER WELDING URANIUM WITHIN THE
PLASTICSSHELLED WORKING SPACE.

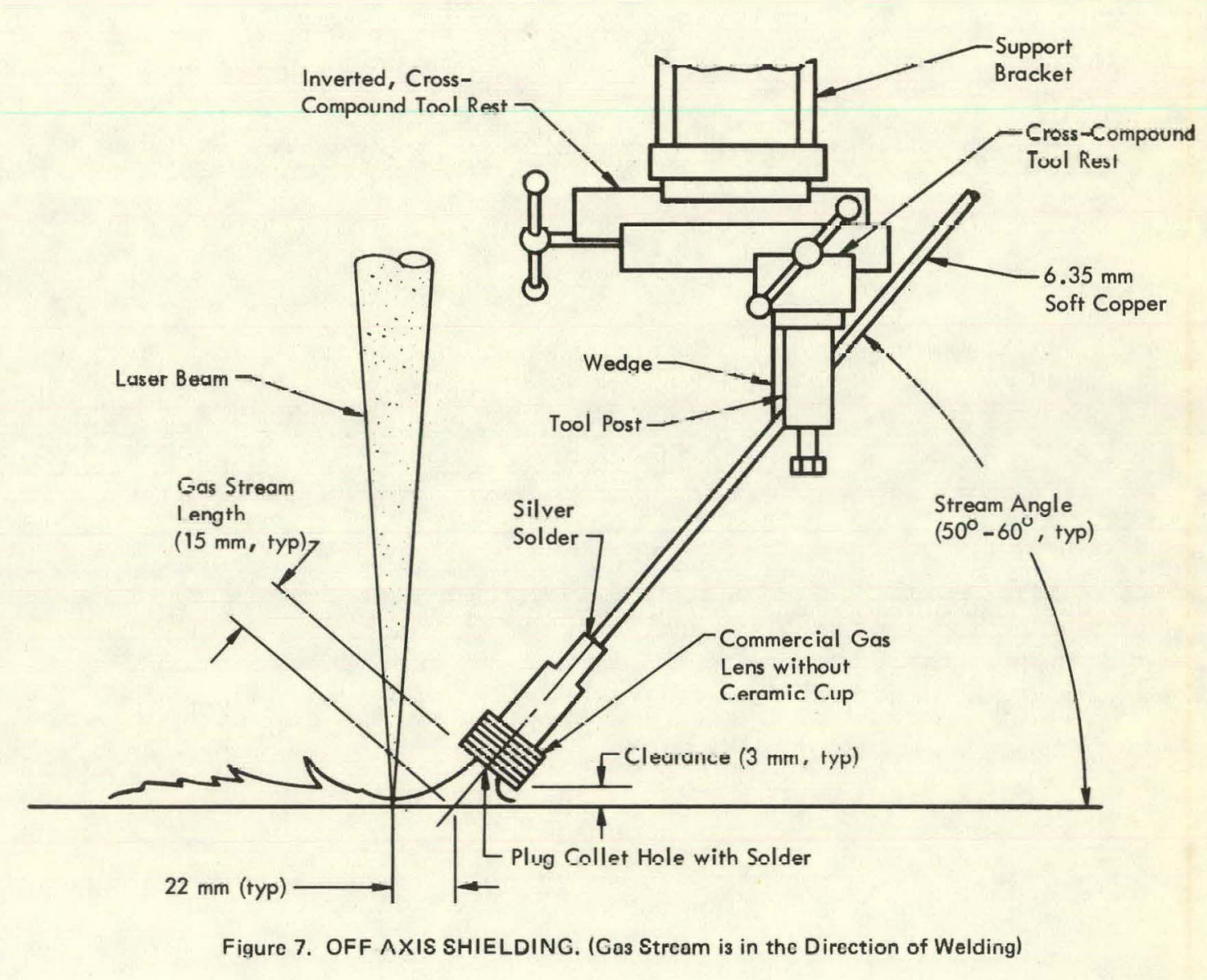

Figure 7. OFF AXIS SHIELDING. IGos Strcam is in the Direction of Welding

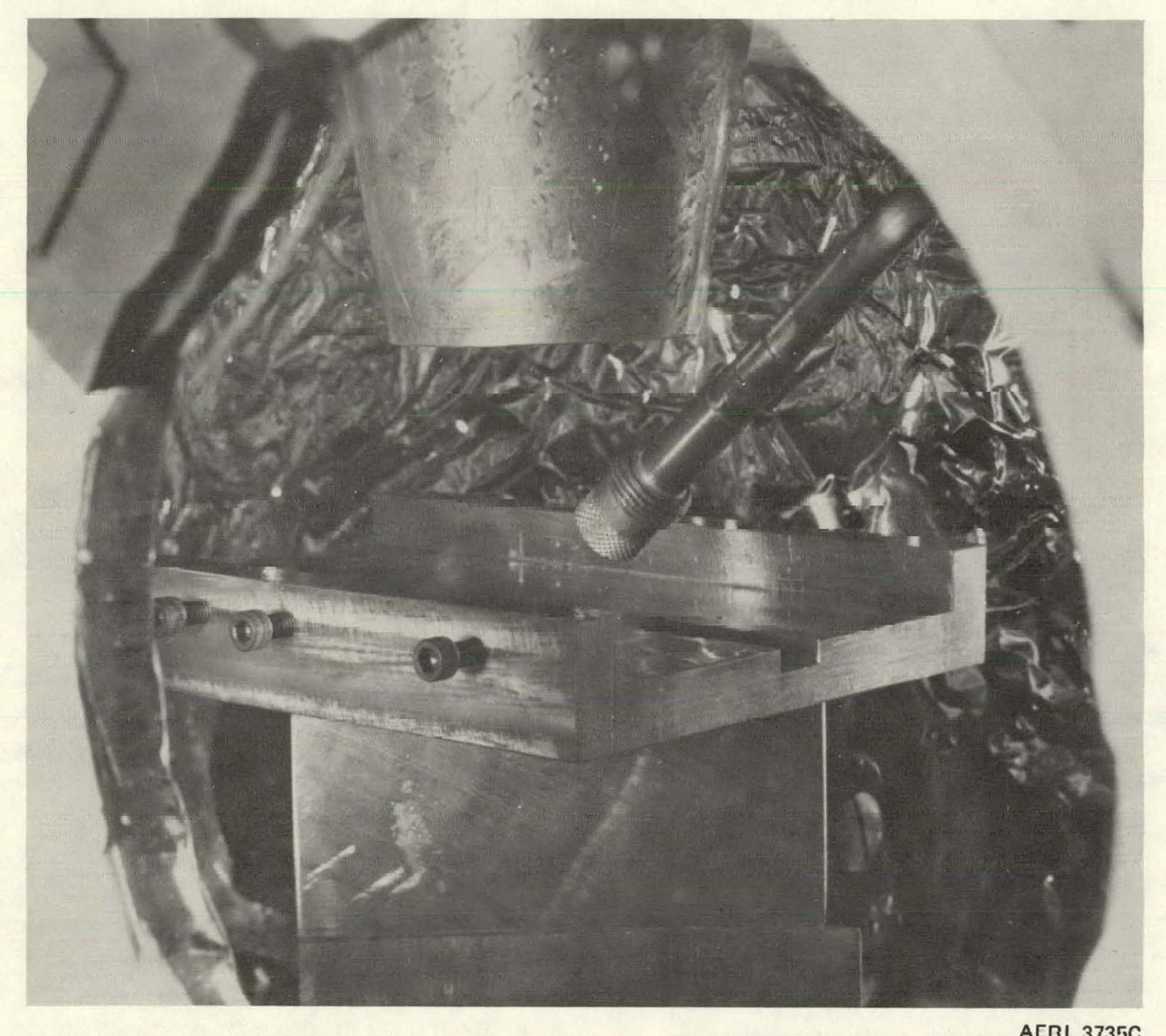

Figur 8. FIXTURE FOR WELDING URANIUM PLATES POSITIONED BENEATH THE OFF-AXIS GAS SHIELLD. 


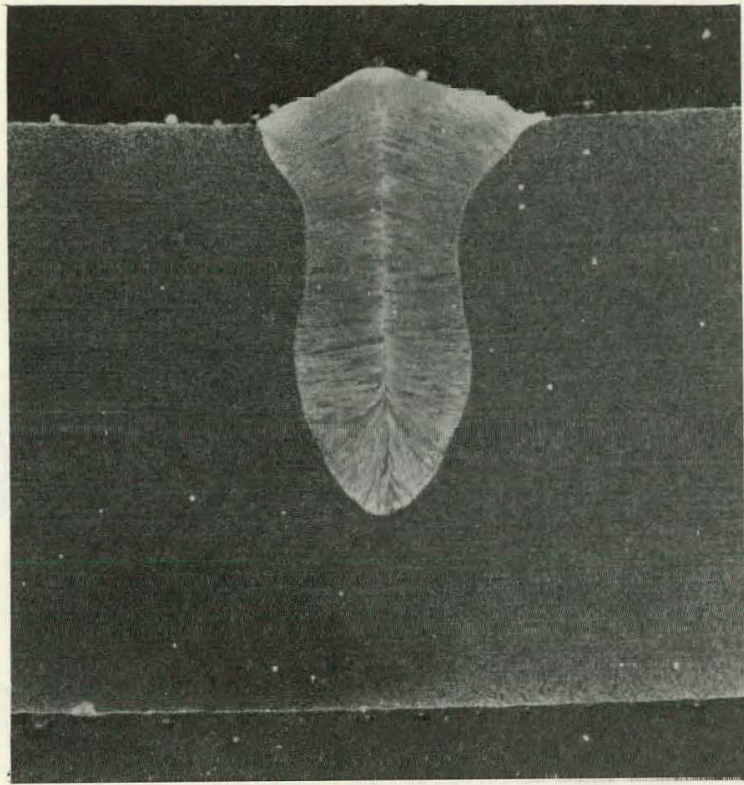

M63-1B

Figure 9. LASER WELD ON AISI 304 STEEL. [Parameters: $6.3 \mathrm{~kW}, 47 \mathrm{~mm} / \mathrm{s}$, and a $710-\mathrm{mm}$ Focal Length (focal point is on the upper surface of the plate); $15 \mathrm{X}$ ]

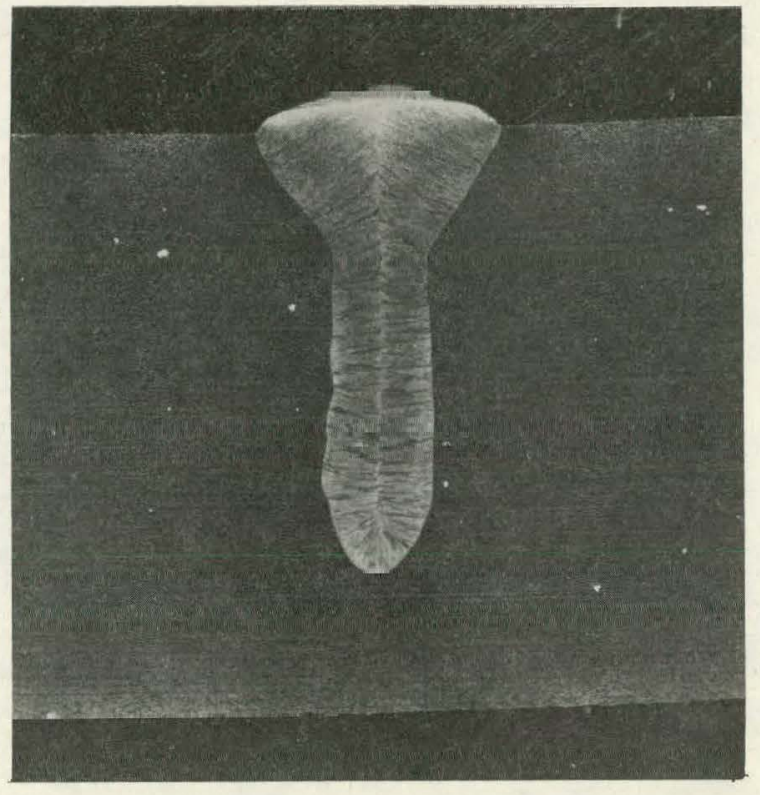

M63-2B

Figure 10. LASER WELD ON AISI 304 STEEL. [Parameters: $6.3 \mathrm{~kW}, 47 \mathrm{~mm} / \mathrm{s}$, and an $800-\mathrm{mm}$ Focal Length (focal point is $3.2 \mathrm{~mm}$ above the upper surface of the plate); 15X]

Trial welds were broken apart to check the uniformity of penetration and soundness along the joint. The width of the face of the weld was measured prior to fracturing the weld. Attempts were made to measure shrinkage transverse to the weld, but there was sufficient angular distortion to cause the measured values $(\sim 0.05 \mathrm{~mm})$ to appear too small.

Parameters were selected from trial weld data to join a series of plates that were returned to the $\mathrm{Y}-12$ Plant for metallographic analysis. Figure 11 shows the layout of these plates for metallographic specimens, and Tables 1 and 2 summarize the result of these examinations. The transverse and longitudinal specimens lie within the view of the face of the weld. The transverse specimens were polished and etched; the longitudinal specimens were held in a vise and broken with a hammer.

Measurement of the dimensions of the welds was derived directly from the photomacrographs, using the known plate features to check the magnification. Penetration was determined from transverse sections by measuring from the parent metal surface to the depth of the fusion zone. Thus, this value (more specifically the depth of fusion) does not coincide with the effective penetration on misaligned joints. The width of the weld used in calculating the depth-to-width ratios is the width of the weld face.

Percent spiking was derived from penetration measurements on longitudinal sections:

$$
\text { Percent Spiking }=\frac{P_{\text {max }}-P_{\text {min }}}{P_{\text {min }}} \times 100 \text {, }
$$




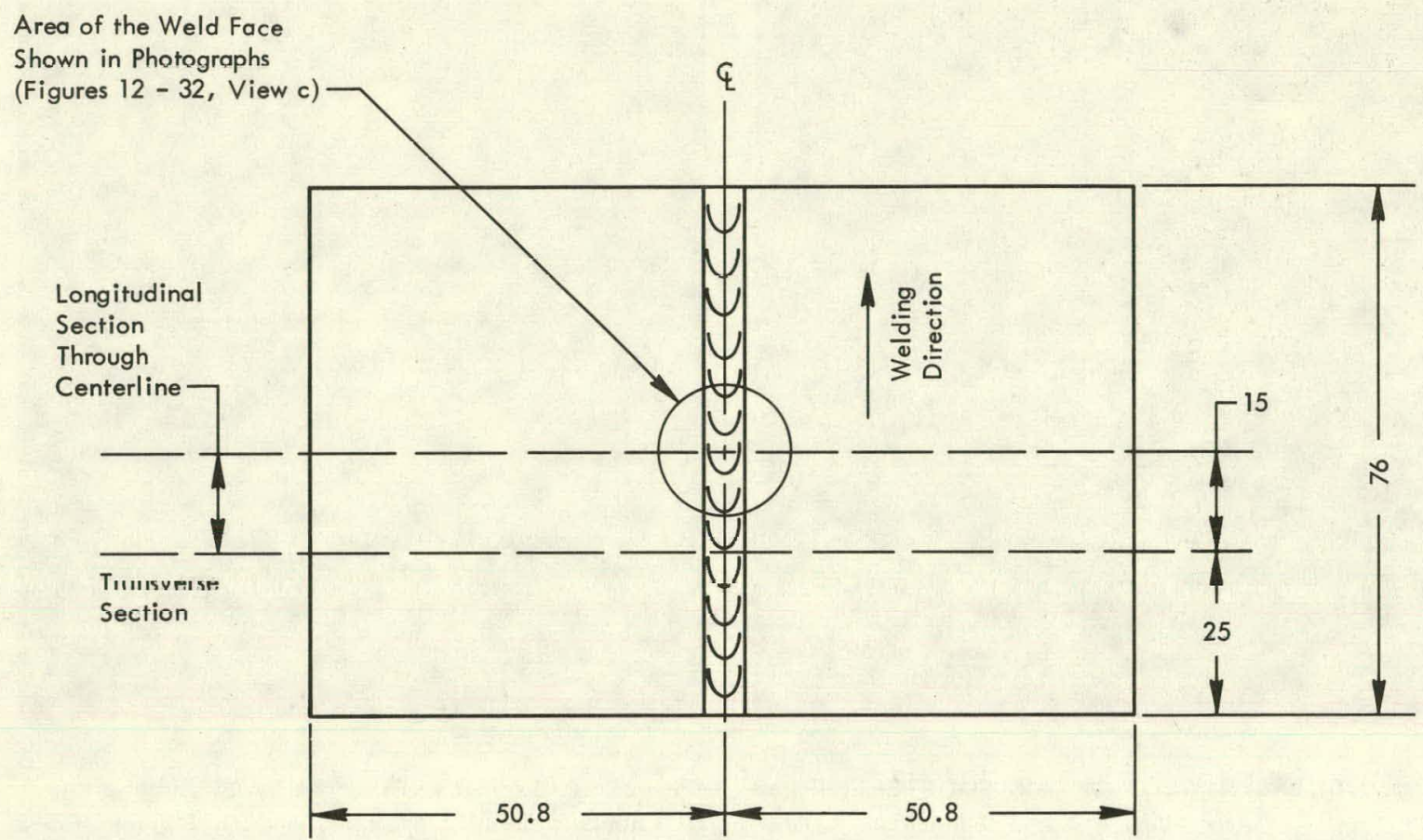

Figure 11. WROUGHT, DEPLETED URANIUM PLATES, 12.7 AND 6.35 MILLIMETERS IN THICKNESS. (Butt Welded by a High-Powered, Continuous-Wave, Carbon Dioxide Laser; All Dimensions are in $\mathrm{mm}$ )

where $P_{\max }$ and $P_{\min }$ are relative to the parent metal surface and do not include weld reinforcement.

All welded joints were radiographed prior to sectioning. Welds $68 \mathrm{G}$ and $69 \mathrm{E}$ (Table 1) and $74 \mathrm{E}$ (Table 2) contained the fewest low-density areas. All remaining welds contained medium to large low-density areas, with Welds $65 \mathrm{E}$ (Table 1) and 71C and 74B (Table 2) containing very large low-density areas.

The photomacrographs in Figures 12 through 32 reveal that high-power, $\mathrm{CO}_{2}$, continuous-wave laser welds have profiles resembling those of deeply penetrated electron-beam welds. Depth-to-width ratios of at least unity are shown to be feasible.

It is apparent that spiking and root defects are also problems in partial-penetration laser welding. The severity of these defects could be decreased by adjustment of the welding parameters. Figures 13 through 15, showing repeated welds, indicate that $50 \%$ penetration in 6.35-mm-thick uranium should be practicable on a production basis. Radiography showed that the repeated welds (Figures 17 to 20) with approximately $75 \%$ penetration all contained large root defects, except the one in Figure 19.

Continuous laser welds in 12.7-mm-thick uranium (Figures 24 to 32) contained more spiking and root defects as penentration increased. Horizontal welds (Figures 28 to 32 ) are well penetrated and have very little undercut. Shielding was not satisfactory on the 
Table 1

LASER WELDS MADE IN THE FLAT POSITION ON 6.35-mm-THICK URANIUM PLATE

\begin{tabular}{|c|c|c|c|c|c|c|c|c|c|c|c|c|c|}
\hline \multirow[b]{2}{*}{ Specimen } & \multirow{2}{*}{$\begin{array}{c}\text { Power to } \\
\text { Work (1) } \\
(\mathrm{kW})\end{array}$} & \multicolumn{2}{|c|}{ Speed } & \multicolumn{2}{|c|}{ Work Distance (2) } & \multicolumn{2}{|c|}{$\begin{array}{c}\text { Width of the Face } \\
\text { of the Weld }\end{array}$} & \multicolumn{2}{|c|}{ Penetration } & \multirow{2}{*}{$\begin{array}{l}\text { Spiking } \\
(\%)\end{array}$} & \multirow{2}{*}{$\begin{array}{l}\text { Depth- } \\
\text { to- } \\
\text { Width } \\
\text { Ratio }\end{array}$} & \multirow{2}{*}{$\begin{array}{c}\text { Specimen } \\
\text { Figure } \\
\text { Number }\end{array}$} & \multirow[b]{2}{*}{ Comments } \\
\hline & & $\overline{(i p m)}$ & $(\mathrm{mm} / \mathrm{s})$ & (in) & $(\mathrm{mm})$ & (in) & $(\mathrm{mm})$ & (in) & $(\mathrm{mm})$ & & & & \\
\hline $65 \mathrm{E}$ & 5.0 & 110 & 47 & 28.000 & 711 & 0.17 & 4.3 & 0.125 & 3.18 & 17.5 & 0.74 & 12 & \\
\hline $68 C$ & 7.4 & 180 & 76 & 28.062 & 713 & 0.14 & 3.6 & 0.150 & 3.81 & 12.0 & 1.07 & 13 & \\
\hline $68 \mathrm{D}$ & 7.4 & 180 & 76 & 28.062 & 713 & 0.14 & 3.6 & 0.140 & 3.56 & 13.5 & 1.00 & 14 & \\
\hline $68 \mathrm{~F}$ & 7.4 & 180 & 76 & 28.062 & 713 & 0.15 & 3.8 & 0.150 & 3.81 & 21.0 & 1.00 & 15 & \\
\hline $68 \mathrm{G}$ & 8.0 & 180 & 76 & 28.062 & 713 & $0.13 / 0.15$ & 3.6 & 0.138 & 3.51 & 47.5 & 0.99 & 16 & $\begin{array}{l}\text { Problems aligning } \\
\text { joint with beam. }\end{array}$ \\
\hline $69 \mathrm{C}$ & 8.4 & 180 & 76 & 28.062 & 713 & $0.14 / 0.16$ & 3.8 & 0.165 & 4.19 & 20.5 & 1.10 & 17 & \\
\hline $69 D$ & 8.4 & 180 & 76 & 28.062 & 713 & $0.14 / 0.17$ & 3.9 & 0.185 & 4.70 & 20.5 & 1.19 & 18 & \\
\hline $69 \mathrm{E}$ & 8.4 & 180 & 76 & 28.062 & 713 & $0.15 / 0.16$ & 3.9 & 0.165 & 4.19 & 31.0 & 1.06 & 19 & \\
\hline $69 \mathrm{~F}$ & 8.4 & 180 & 76 & 28.062 & 713 & 0.16 & 4.1 & 0.180 & 4.57 & 23.5 & 1.13 & 20 & \\
\hline $69 \mathrm{G}$ & 8.0 & 180 & 76 & 28.000 & 711 & $0.15 / 0.17$ & 4.1 & 0.170 & 4.32 & 21.0 & 1.06 & 21 & \\
\hline $70 \mathrm{C}$ & 8.0 & 250 & 106 & 28.000 & 711 & $0.13 / 0.15$ & 3.6 & 0.120 & 3.05 & 103.5 & 0.86 & 22 & \\
\hline 70D & 10.2 & 250 & 106 & 28.000 & 711 & $0.12 / 0.15$ & 3.4 & 0.188 & 4.78 & 76.0 & 1.39 & 23 & \\
\hline
\end{tabular}

(1) Loss in the optical path is $30 \%$ of the power from the laser cavity.

(2) Minimum beam diameter is at a $711-\mathrm{mm}$ (28-in) telescope-to-work distance. 
Table 2

L.ASER WELDS ON 12.7-mm-THICK P_ATE IN BOTH THE FLAT AND HORIZONTAL FOSITIONS

\begin{tabular}{|c|c|c|c|c|c|c|c|c|c|c|c|c|c|}
\hline \multirow[b]{2}{*}{ Specimen } & \multirow{2}{*}{$\begin{array}{l}\text { Power to } \\
\text { Work (1) } \\
\text { (kW) }\end{array}$} & \multicolumn{2}{|c|}{ Speed } & \multicolumn{2}{|c|}{ Work Distance ${ }^{(2)}$} & \multicolumn{2}{|c|}{$\begin{array}{l}\text { Width of the Face } \\
\text { of the Weld }\end{array}$} & \multicolumn{2}{|c|}{ Pene-ration } & \multirow{2}{*}{$\begin{array}{l}\text { Spiking } \\
(\%)\end{array}$} & \multirow{2}{*}{$\begin{array}{l}\text { Depth- } \\
\text { to- } \\
\text { Width } \\
\text { Ratio }\end{array}$} & \multirow{2}{*}{$\begin{array}{c}\text { Specimen } \\
\text { Figure } \\
\text { Number }\end{array}$} & \multirow[b]{2}{*}{ Comments } \\
\hline & & $\overline{(i p m)}$ & $(\mathrm{mm} / \mathrm{s})$ & (in) & $(\mathrm{mm})$ & (in) & $(\mathrm{mm})$ & (in) & $(\mathrm{mm})$ & & & & \\
\hline $71 \mathrm{E}^{(3)}$ & 12.6 & 130 & 55 & 28.062 & 713 & C. 24 & 6.10 & 0.225 & 5.72 & NA & 0.94 & 24 & Bead on the plate. \\
\hline $71 \mathrm{c}^{(3)}$ & 12.9 & 130 & 55 & 28.062 & 713 & 0.18 & 4.57 & 0.393 & 10.11 & 28.0 & 2.21 & 25 & \\
\hline $71 \mathrm{~F}^{(3)}$ & 12.6 & 130 & 55 & 28.062 & 713 & 0.22 & 5.59 & 0.345 & 8.76 & 8.0 & 1.57 & 26 & $\begin{array}{l}\text { Used an auxiliary } \\
\text { helium shield. }\end{array}$ \\
\hline $72 \mathrm{~B}^{(3)}$ & 9.1 & 75 & 32 & 28.062 & 713 & 0.31 & 7.87 & 0.345 & 8.76 & 14.0 & 1.11 & 27 & \\
\hline $74 \mathrm{~B}^{(4)}$ & 9.1 & 75 & 32 & 28.000 & 711 & 0.25 & 6.35 & 0.263 & 6.81 & 9.5 & 1.07 & 28 & Back-welded plate. \\
\hline $74 C^{(4)}$ & 9.1 & 75 & 32 & 28.000 & 711 & 0.20 & 5.08 & 0.263 & 6.81 & 14.0 & 1.34 & 29 & \\
\hline $74 D^{(4)}$ & 11.9 & 130 & 55 & 28.062 & 713 & 0.14 & 3.56 & 0.233 & 6.05 & 18.5 & 1.70 & 30 & \\
\hline $74 \mathrm{E}^{(4)}$ & 7.4 & 175 & 76 & 28.062 & 713 & 0.12 & 3.05 & 0.123 & 3.25 & 12.0 & 1.07 & 31 & \\
\hline $74 \mathrm{~F}^{(4)}$ & 8.4 & 175 & 76 & 28.062 & 713 & 0.10 & 2.54 & 0.157 & 4.04 & 12.0 & 1.59 & 32 & \\
\hline
\end{tabular}

(1) Loss in the optical pat? is $30 \%$ of -he power from the laser cavity.

(2) Minimum beam diameter is at a $7 \uparrow 1-\mathrm{mm}$ (28-in) telescope-to-vork distarce.

(3) Welds made in the flat position.

(4) Welds made in the hor zontal position. 

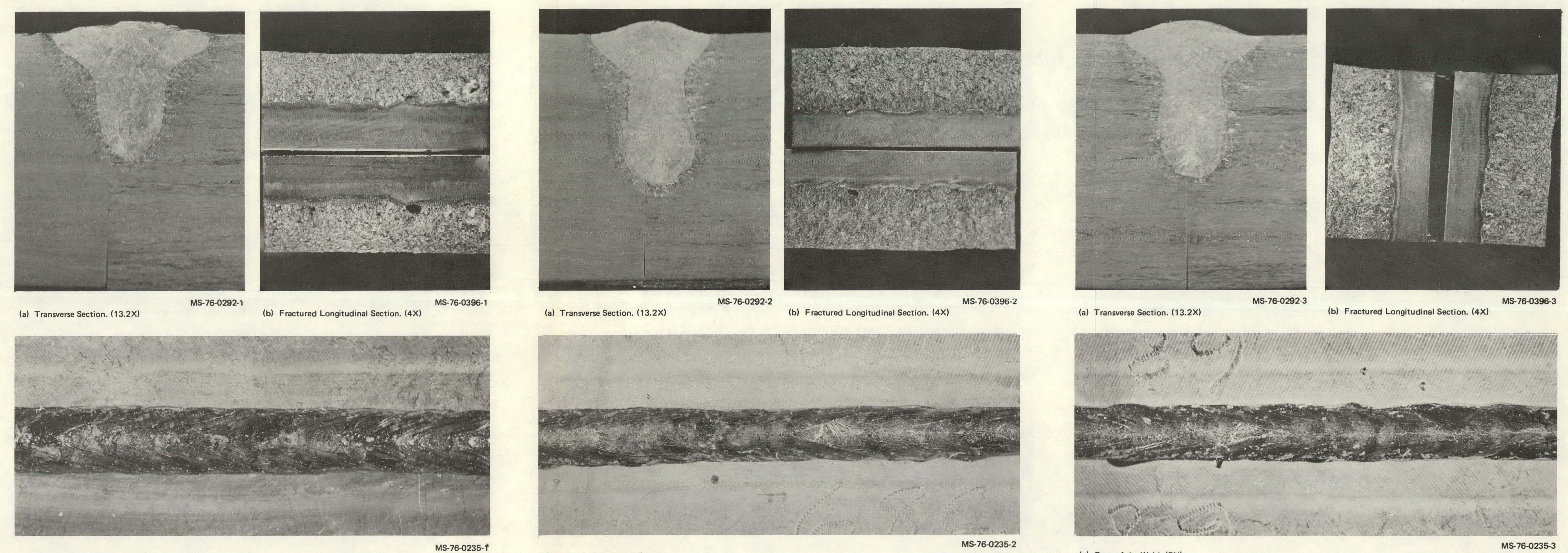

(a) Transverse Section. (13.2x)

MS-76-0292.3

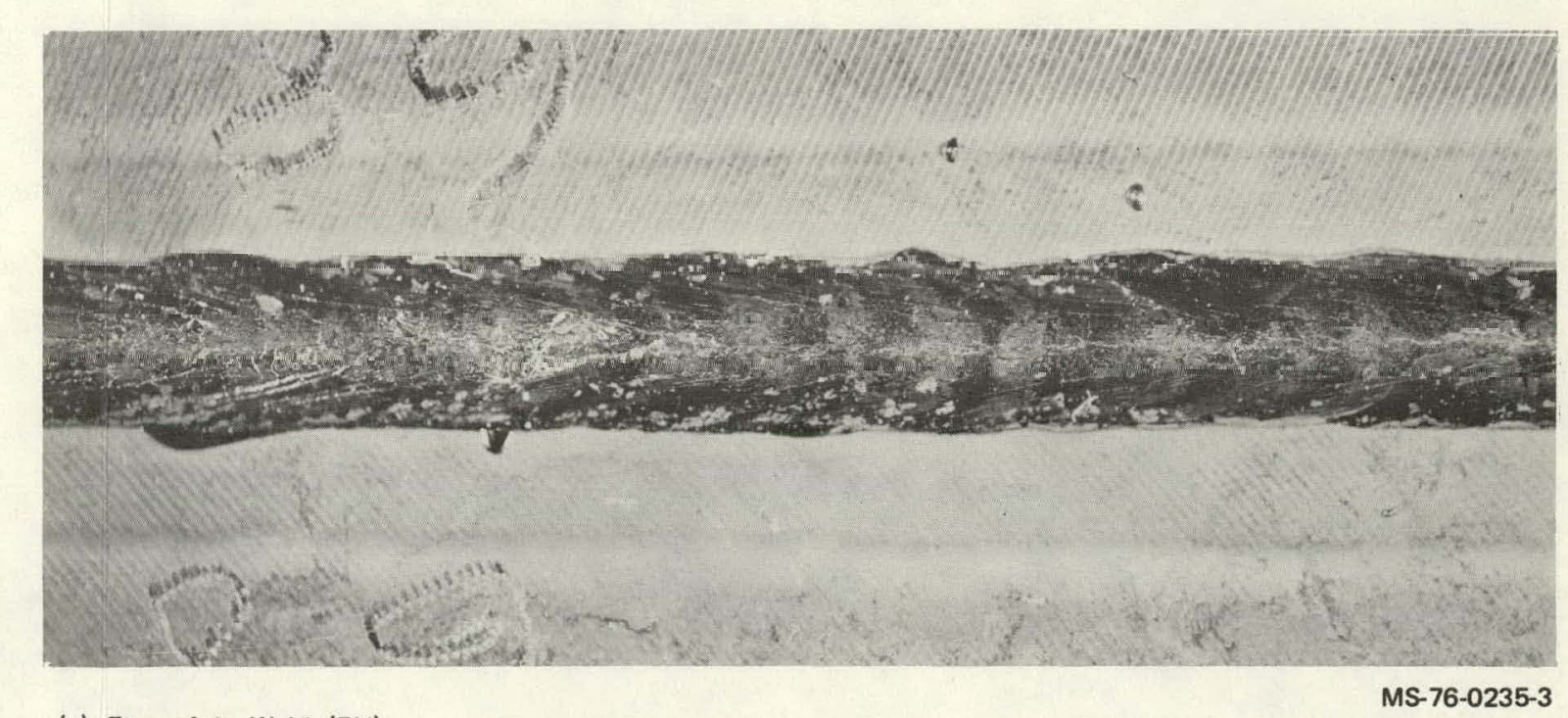

(c) Face of the Weld. (5x)

MS-78-0235-t

(1)

(c) Face of the Weld. (5x)

MS-76-0235-2

Figure 13. MACROGRAPHS OF WELD 68C. $17.4 \mathrm{~kW}: 76 \mathrm{~mm} / \mathrm{ss}$ Sharp Focus $+1.6 \mathrm{~mm}$

(c) Face of the Weld. 15x) Figure 14. MACROGRAPHS OF WELD 68D. $17.4 \mathrm{~kW} ; 76 \mathrm{~mm} / \mathrm{ss}$ : Sharp Focus $+1.6 \mathrm{~mm}$ 

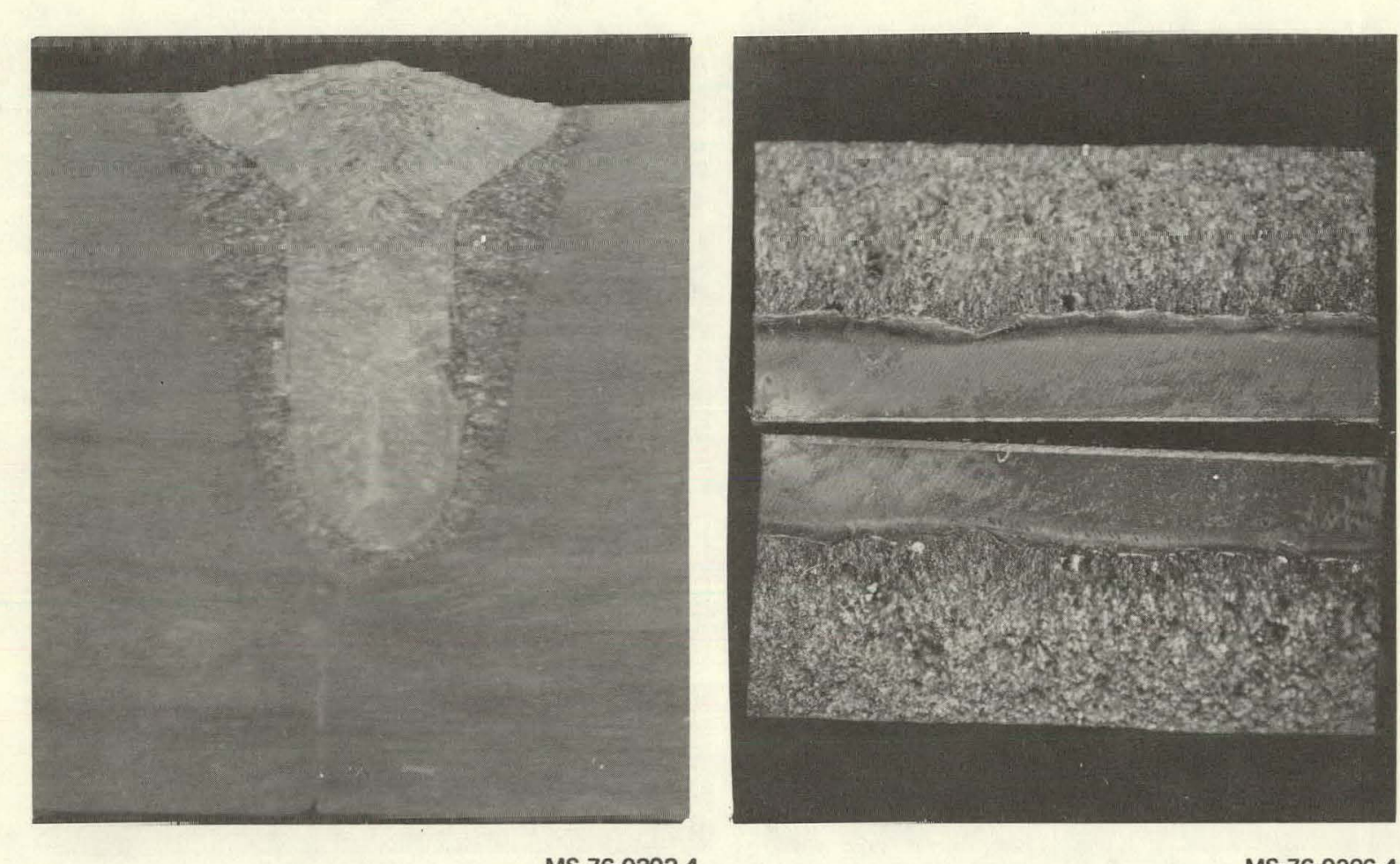

(a) Transverse Section. (13.2x)

MS-76-0292-4

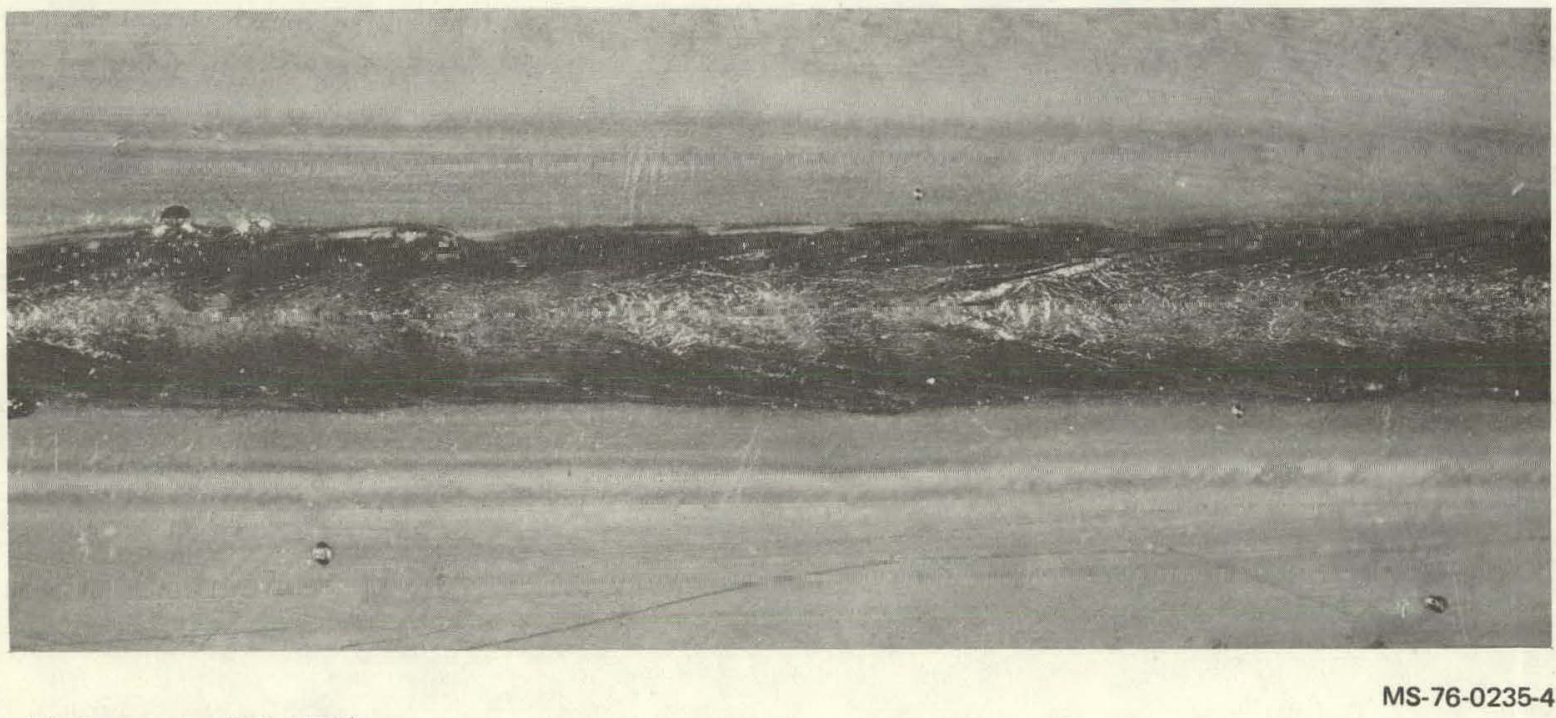

(c) Face of the Weld. (5x)

MS-76-0235-4

15. MACROGRAPHS OF WELD 68F. $17.4 \mathrm{~kW} ; 76 \mathrm{~mm} / \mathrm{s}$ : Sharp Focus $+1.6 \mathrm{~m}$

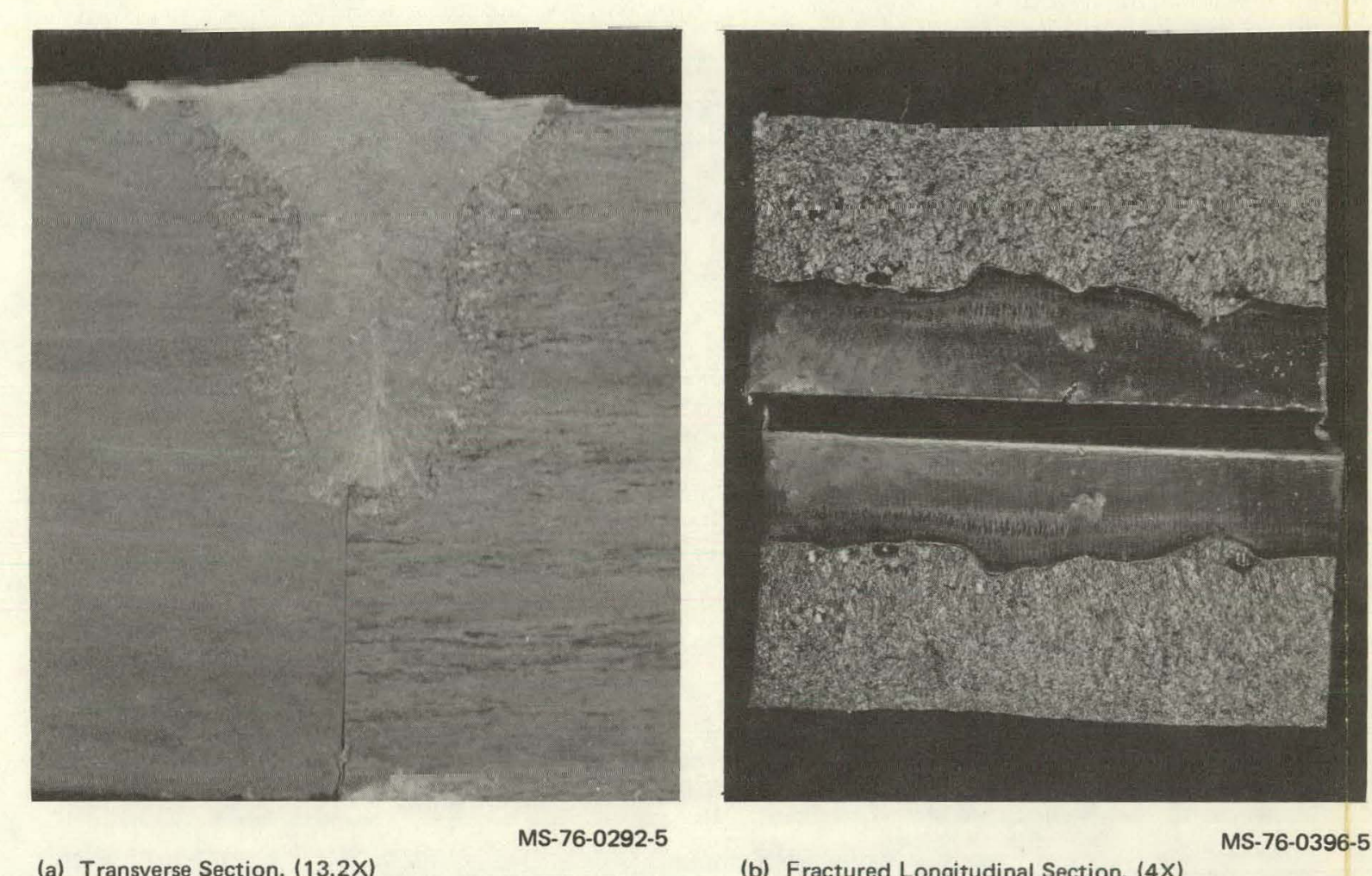

MS-76.0396-5

(a) Transverse Section. (13.2x)

Ms-76-0222:-5

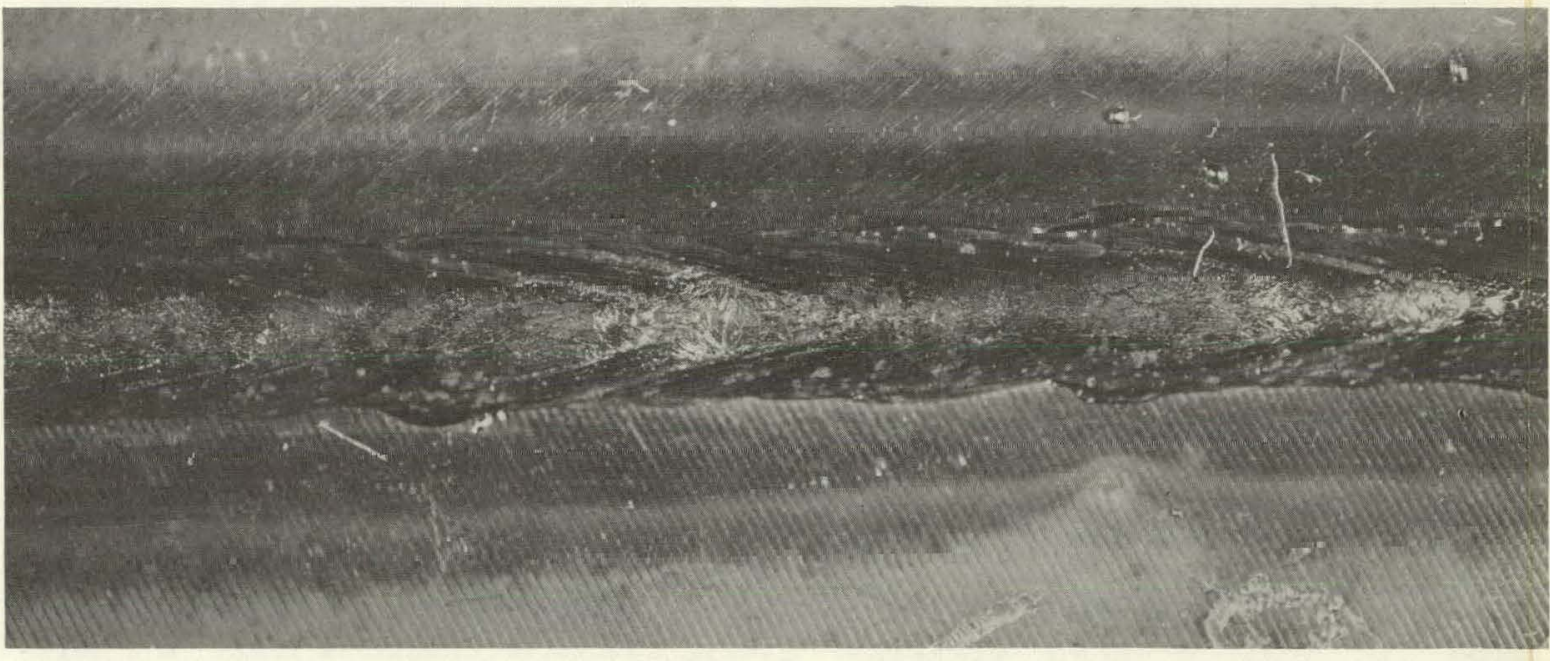

(c) Face of the Weld. (5x) MS.76-0235.5

Figure 16. MACROGRAPHS OF WFLD 68G. $(8.0 \mathrm{kN} ; 76 \mathrm{~mm} / 5$; Sharp Focus $+1.6 \mathrm{~mm})$
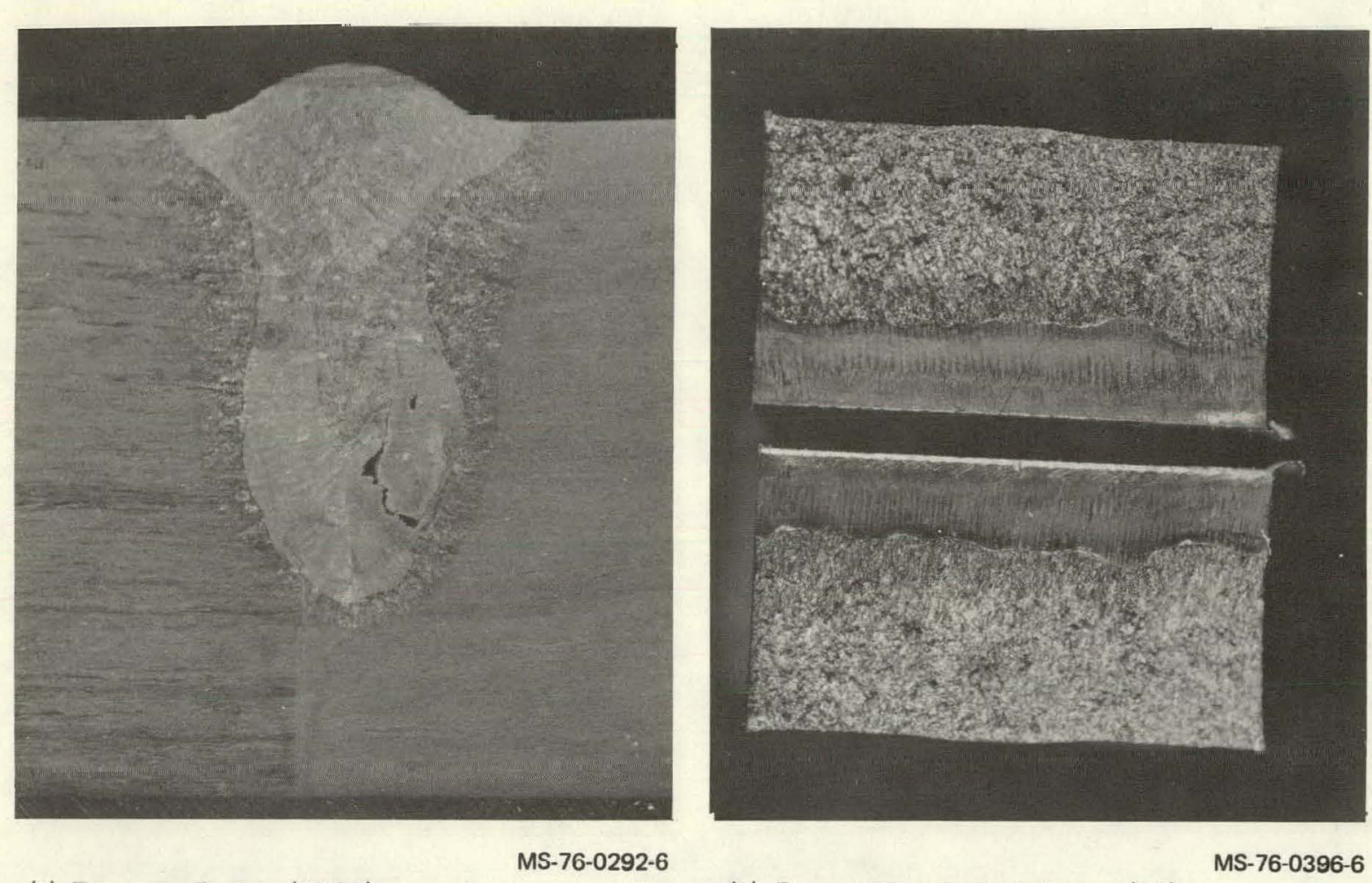

(a) Transverse Section. (13.2x

Ms-76-0292-6

(b) Fractured Longitudinal Section. $14 x$

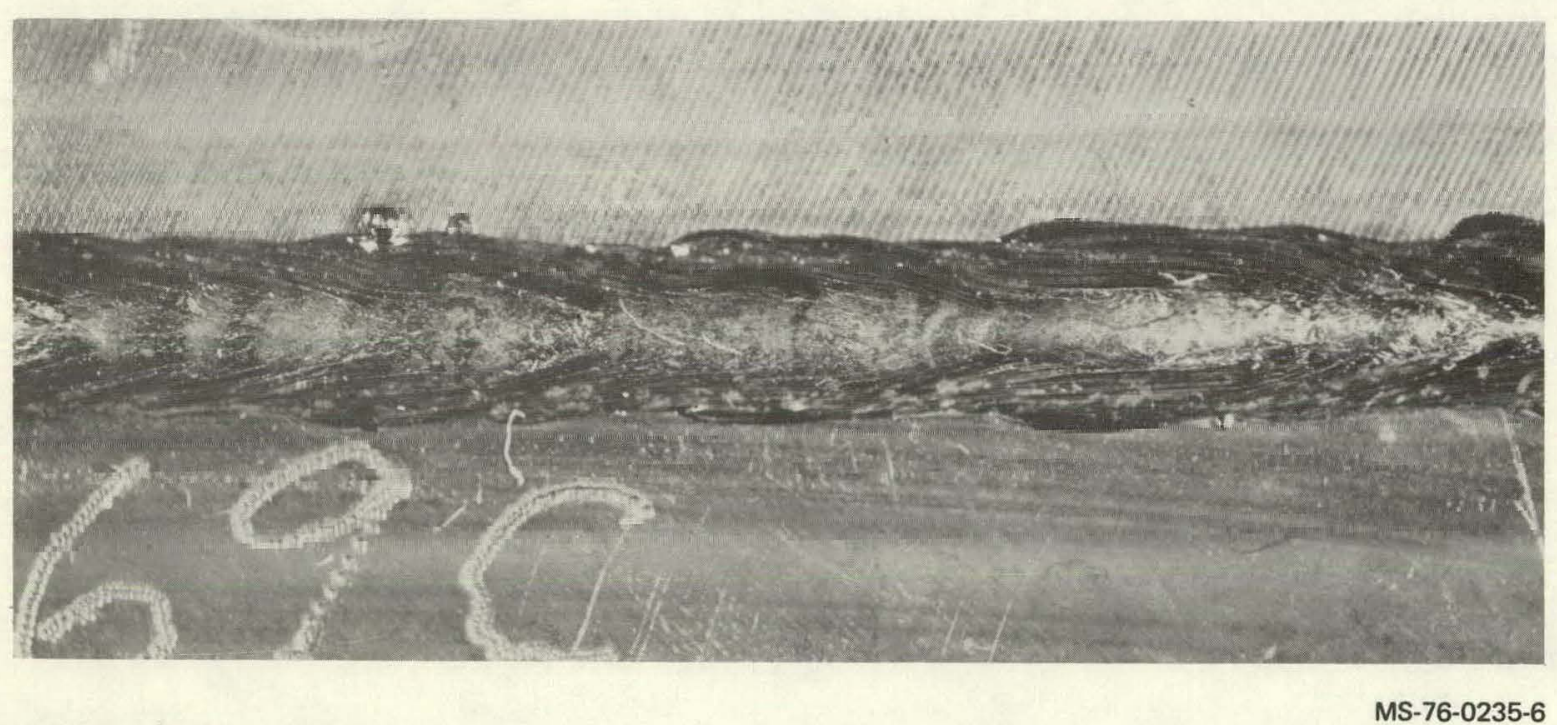

(c) Face of the Weld. (5x)

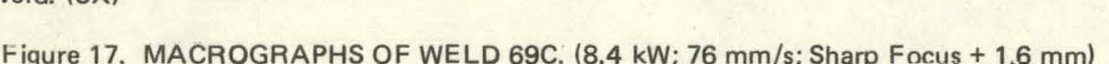



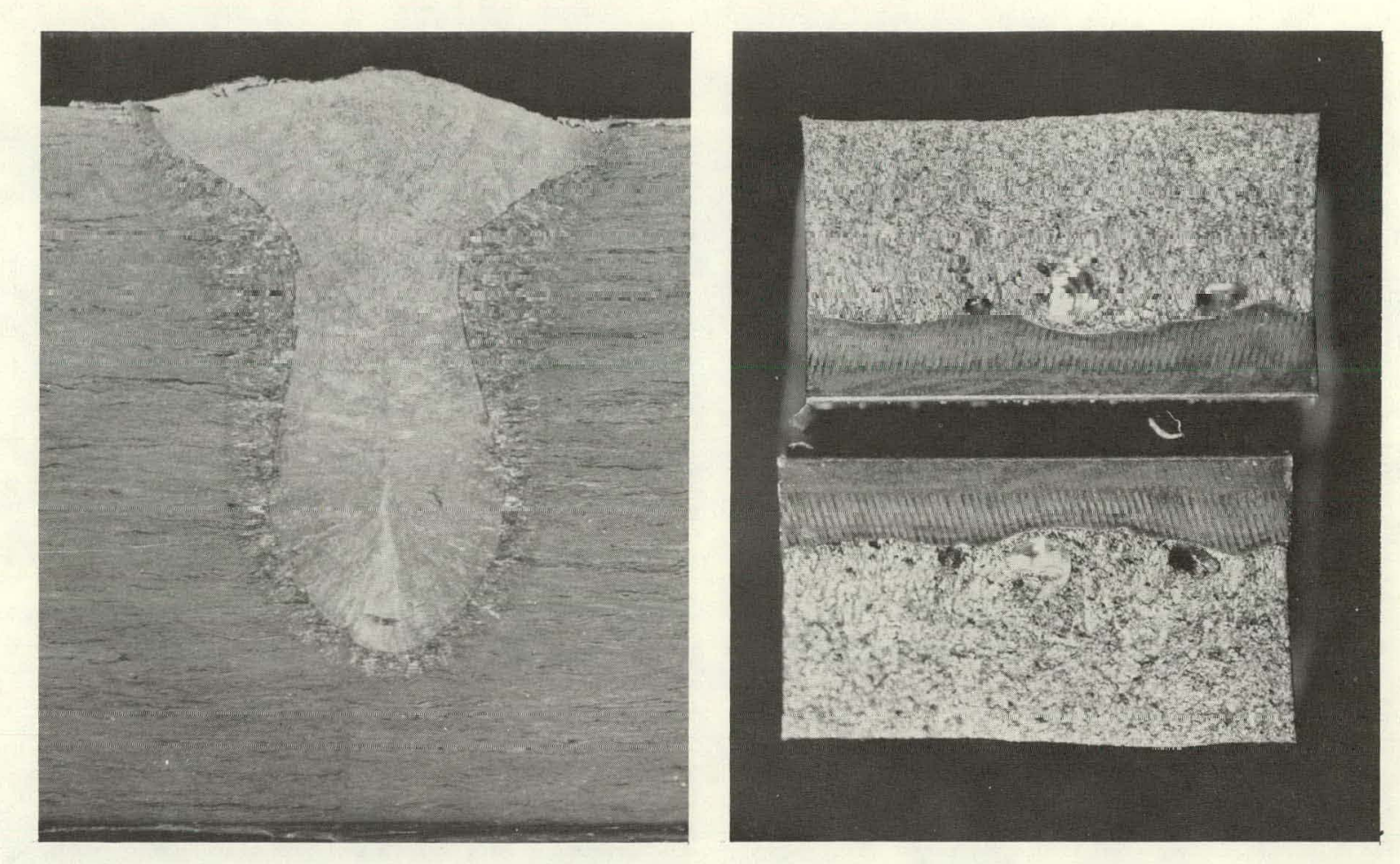

(a) Transverse Section. (13.2x)

MS-76-0292-7
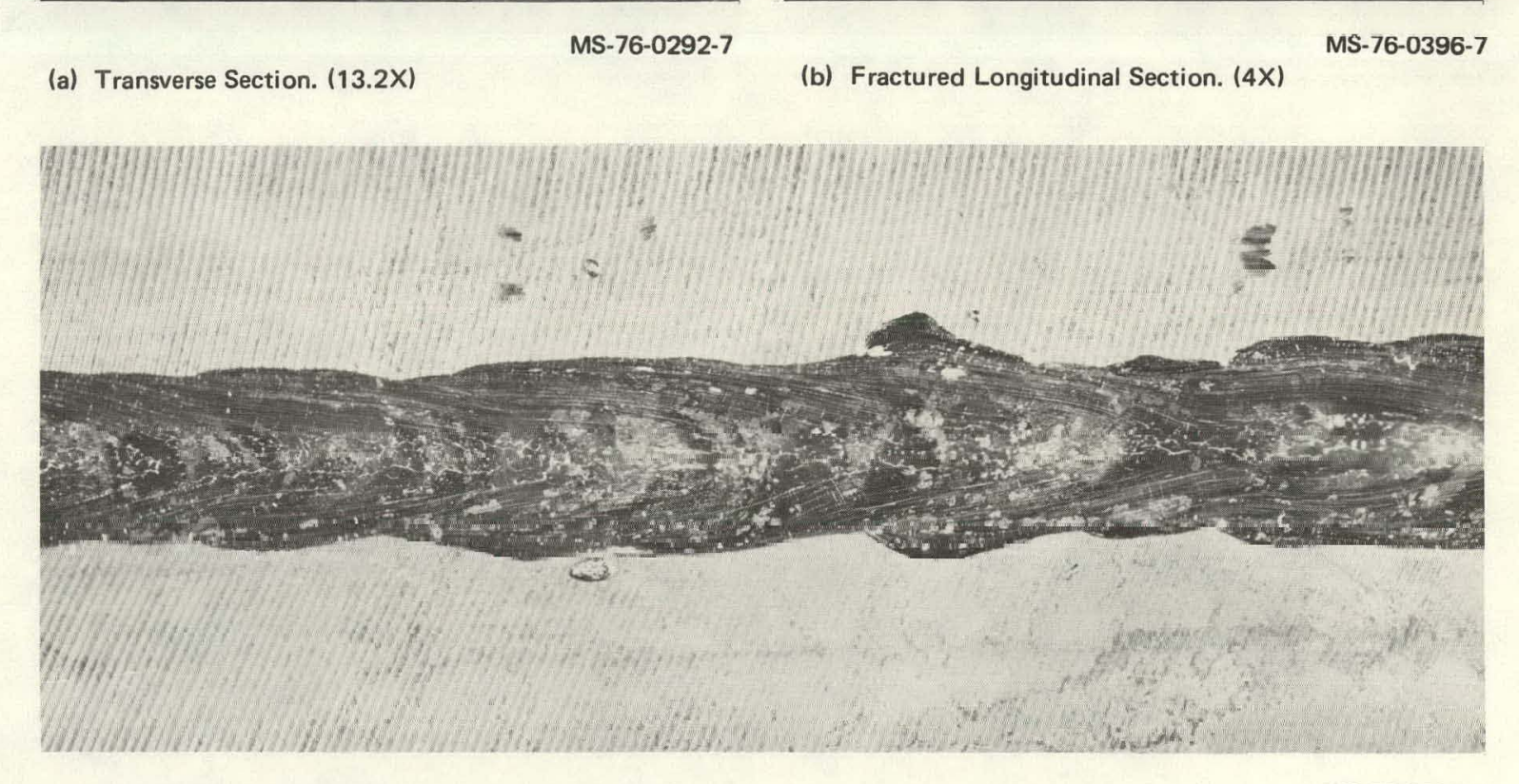

(c) Face of the Weld. (5x)

Ms-76-0235-7 Figure 18. MACROGRAPHS OF WELD 69D. $18.4 \mathrm{~kW} ; 76 \mathrm{~mm} / \mathrm{s}$; Sharp Focus $+1.6 \mathrm{~mm})$
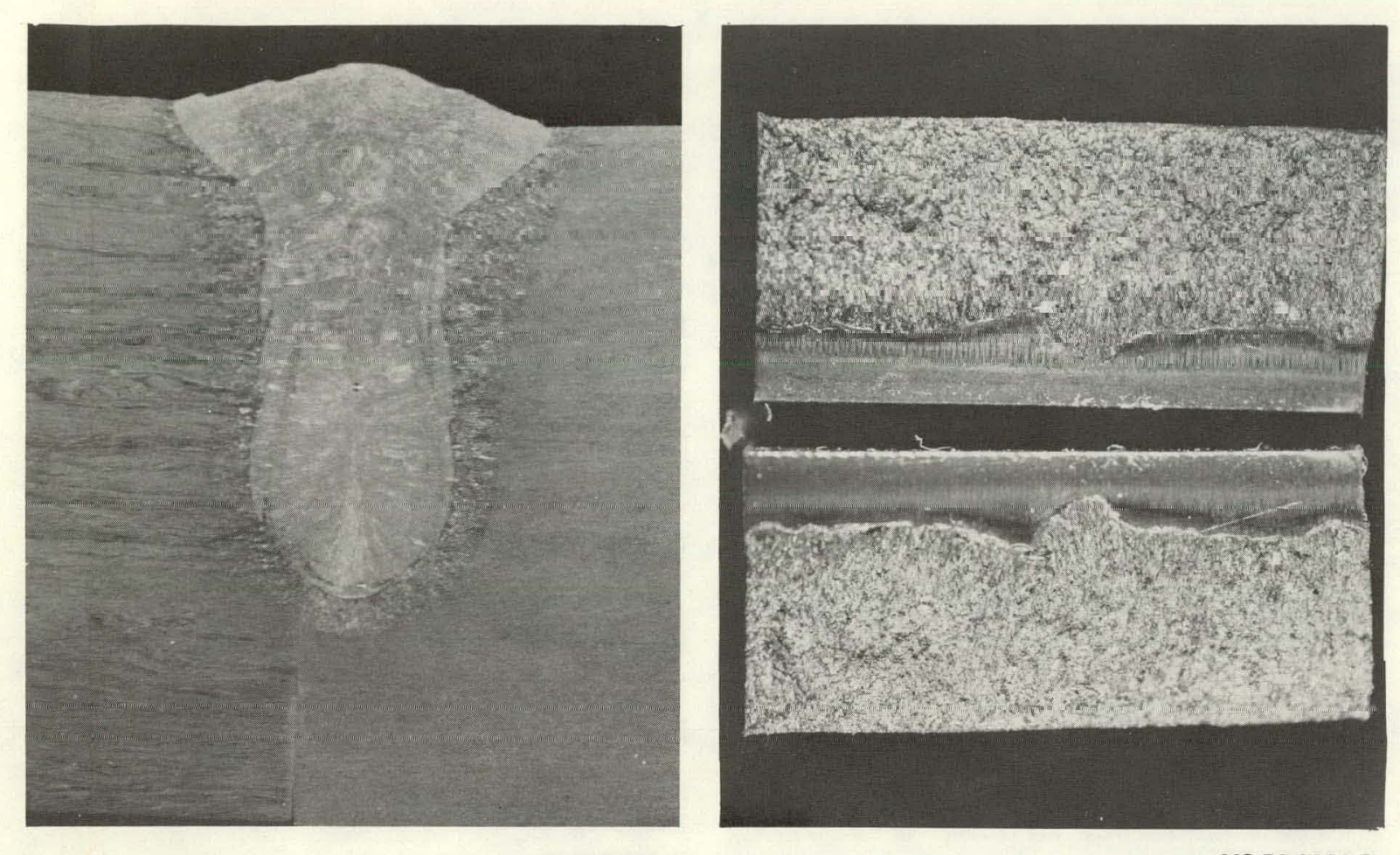

(a) Transverse Section. (13.2x)

MS-76-0292-8

(b) Fractured Longitudinal Section. (4x)

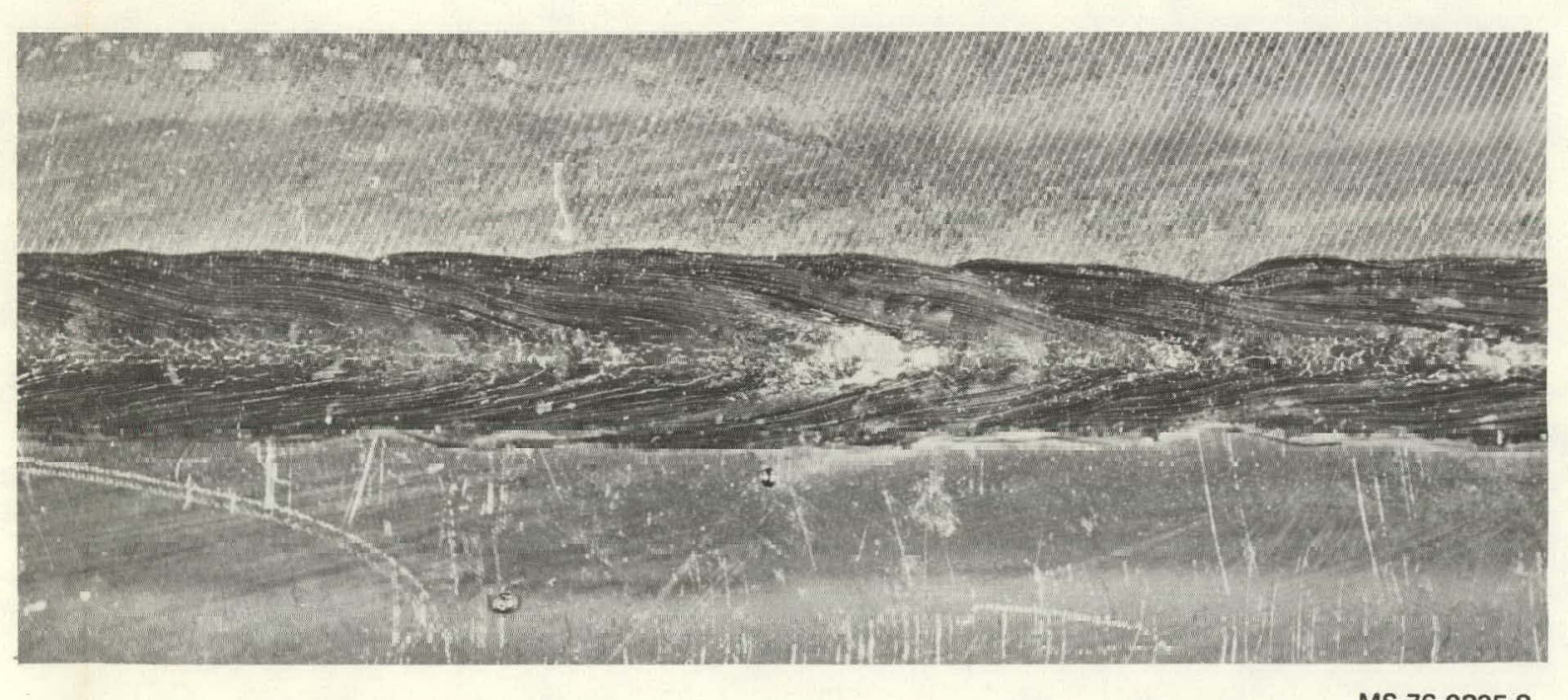

(c) Face of the Weld. (5x)

Figure 19. MACROGRAPHS OF WELD 695 . $18.4 \mathrm{~kW} ; 76 \mathrm{~mm} / \mathrm{s}$; Sharp Focus $+1.6 \mathrm{~mm})$
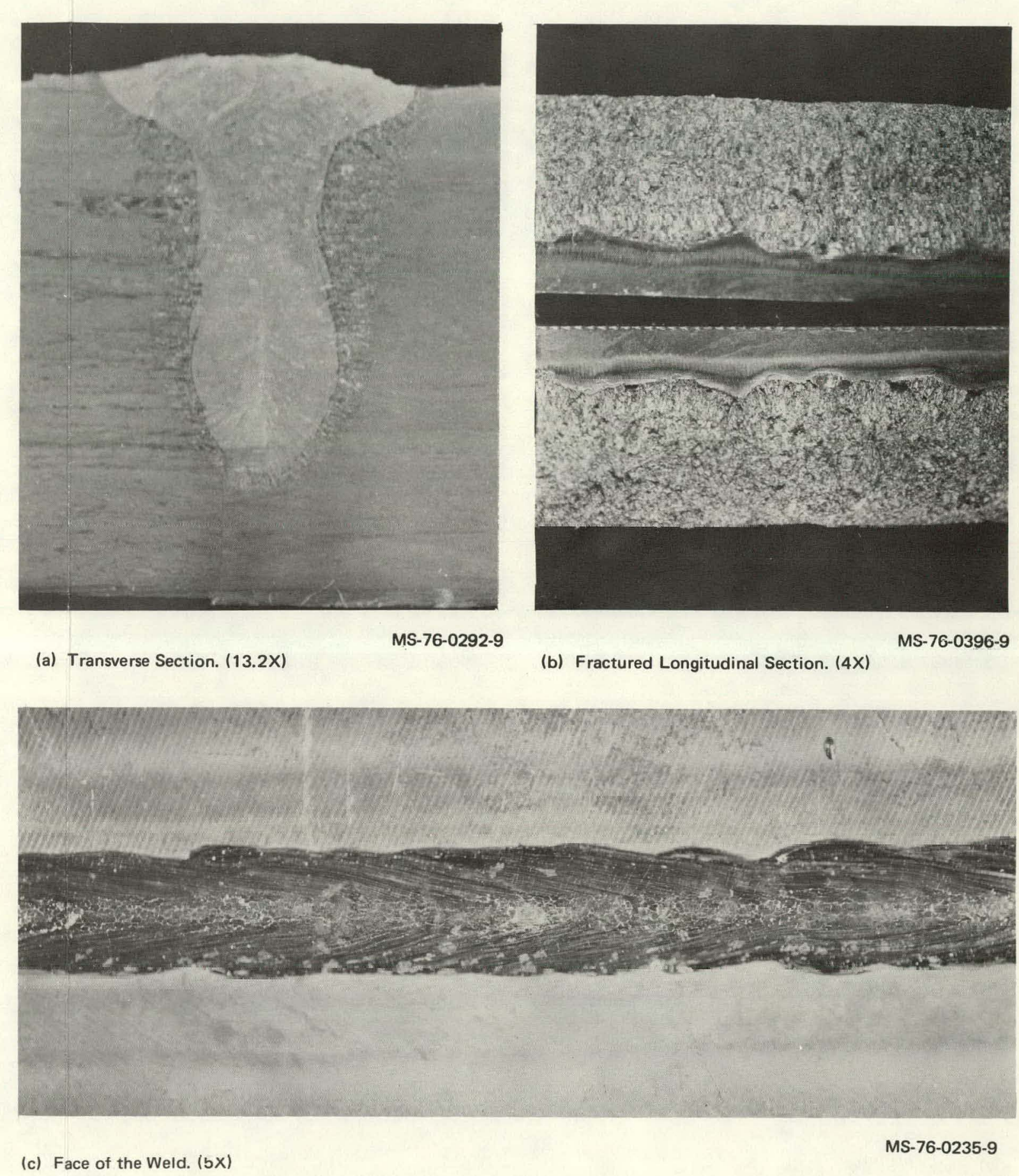

Figure 20. MACROGRAPHS OF WELD 69F. $18.4 \mathrm{~kW} ; 76 \mathrm{~mm} / \mathrm{s}$; Sharp Focus $+1.6 \mathrm{~mm}$ 

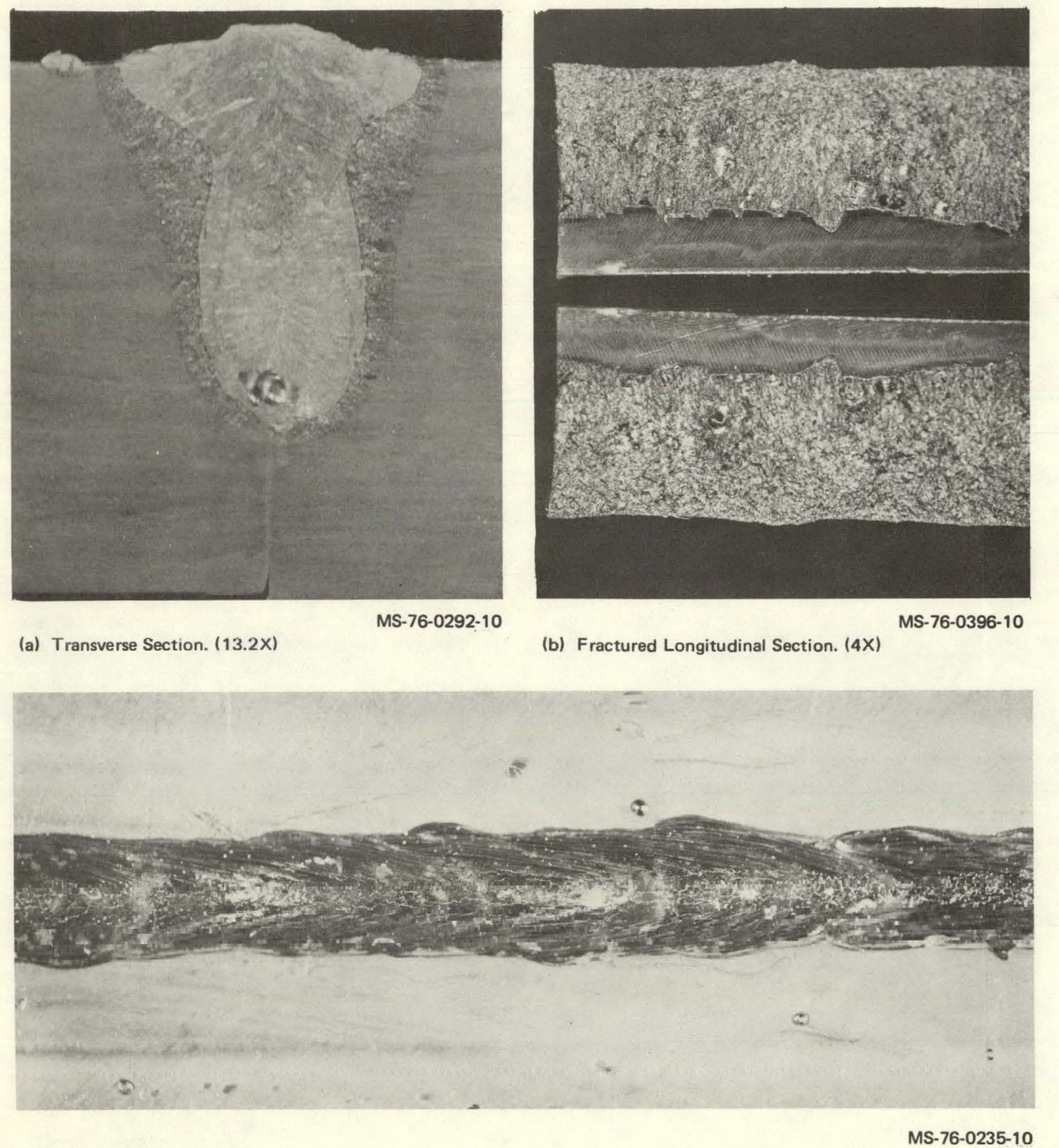

(c) Face of the Weld. (5x)

Figurr 21. MACROGAAPHS OF WELD 69G. $18.0 \mathrm{~kW} ; 76 \mathrm{~mm} / \mathrm{ss}$; Sharp Focus
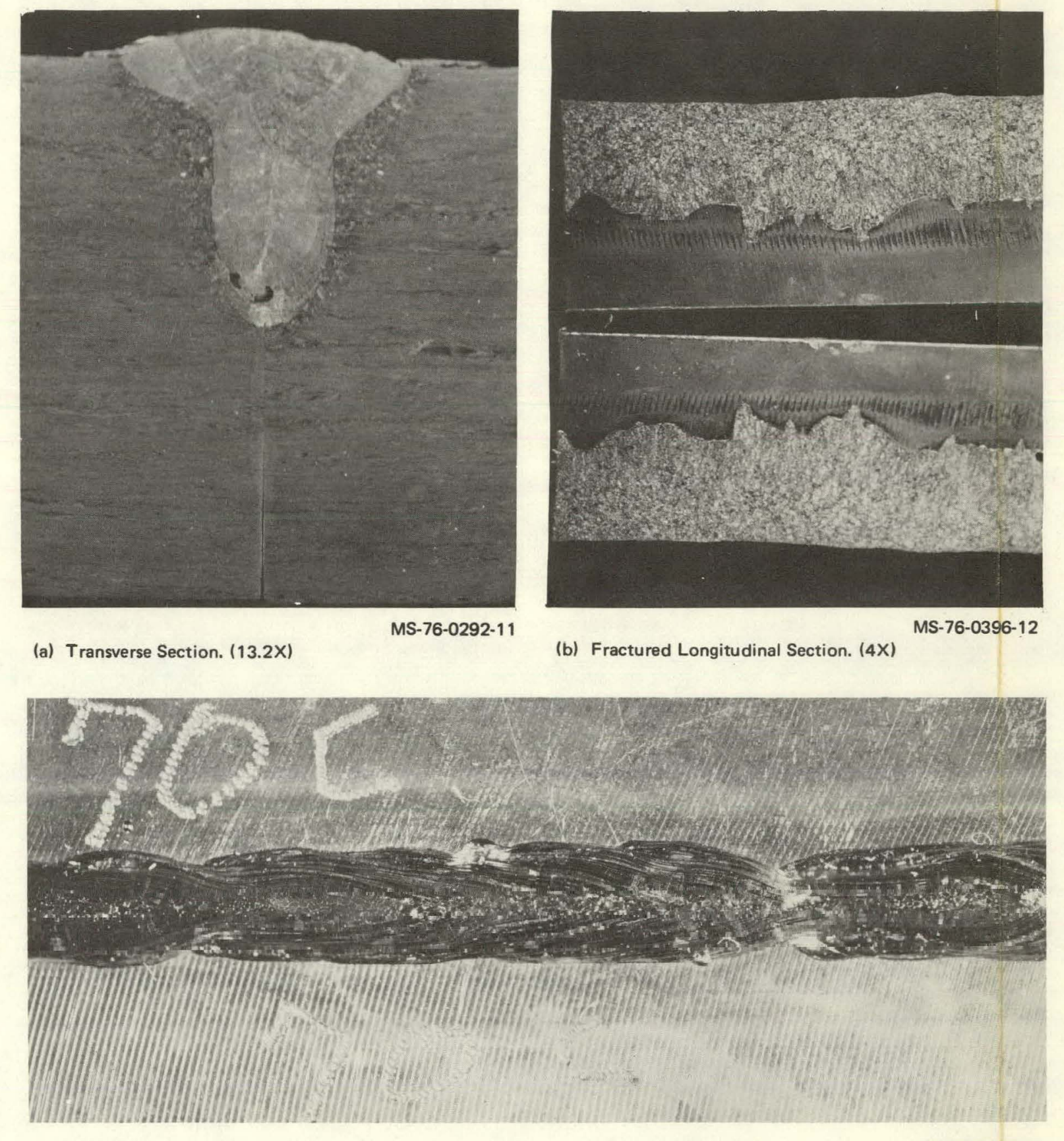

(c) Face of the Weld. (5x)

Figure 22. MACROGRAPHS OF WELD 70 C. $18.0 \mathrm{~kW} ; 106 \mathrm{~mm} / \mathrm{s}$; Sharp Focus
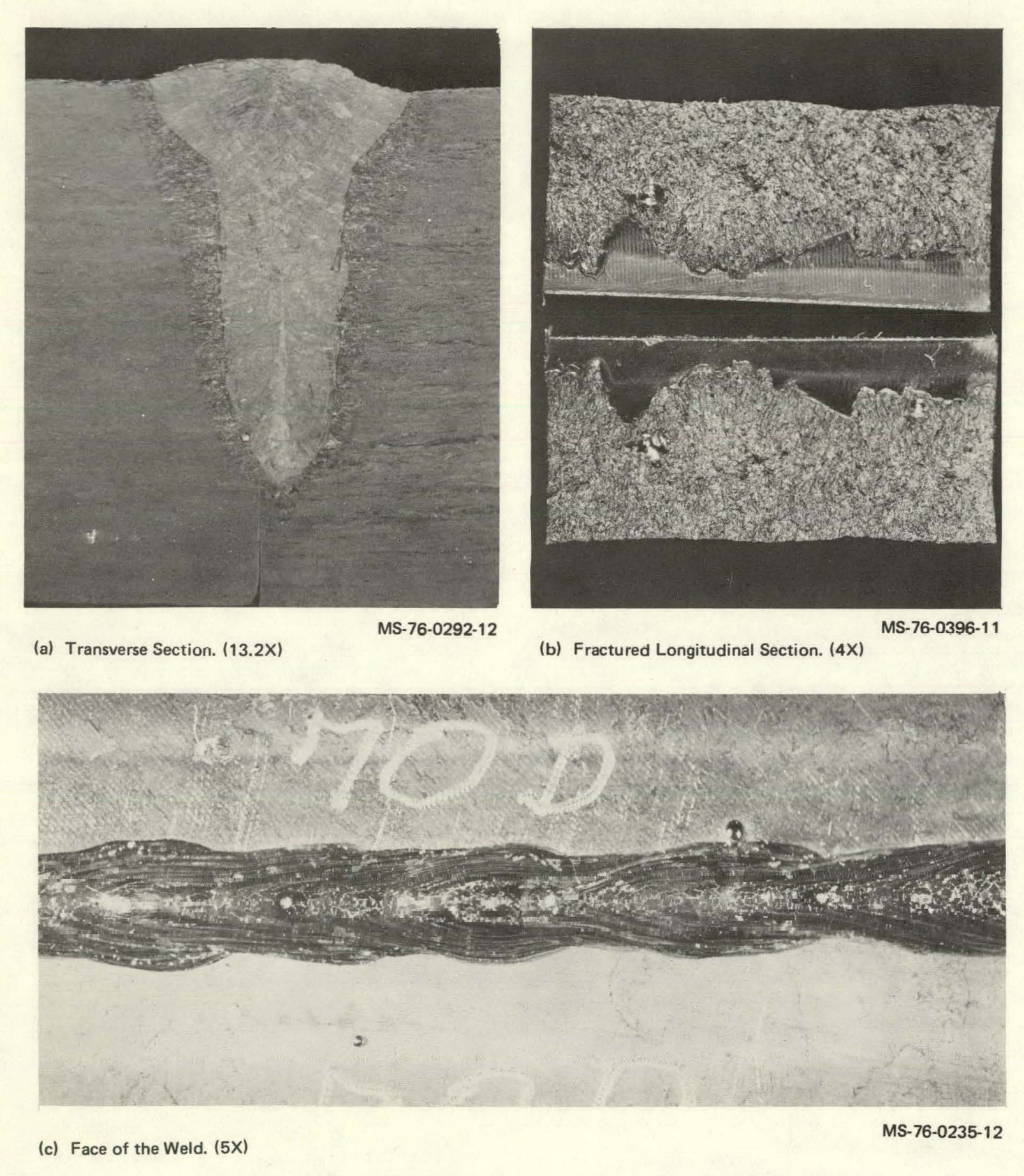

Figure 23. MACROGRAPHS OF WELD 70D. (10.2 kW: $100 \mathrm{~mm} / \mathrm{s}$, Shatry Fuvus) 


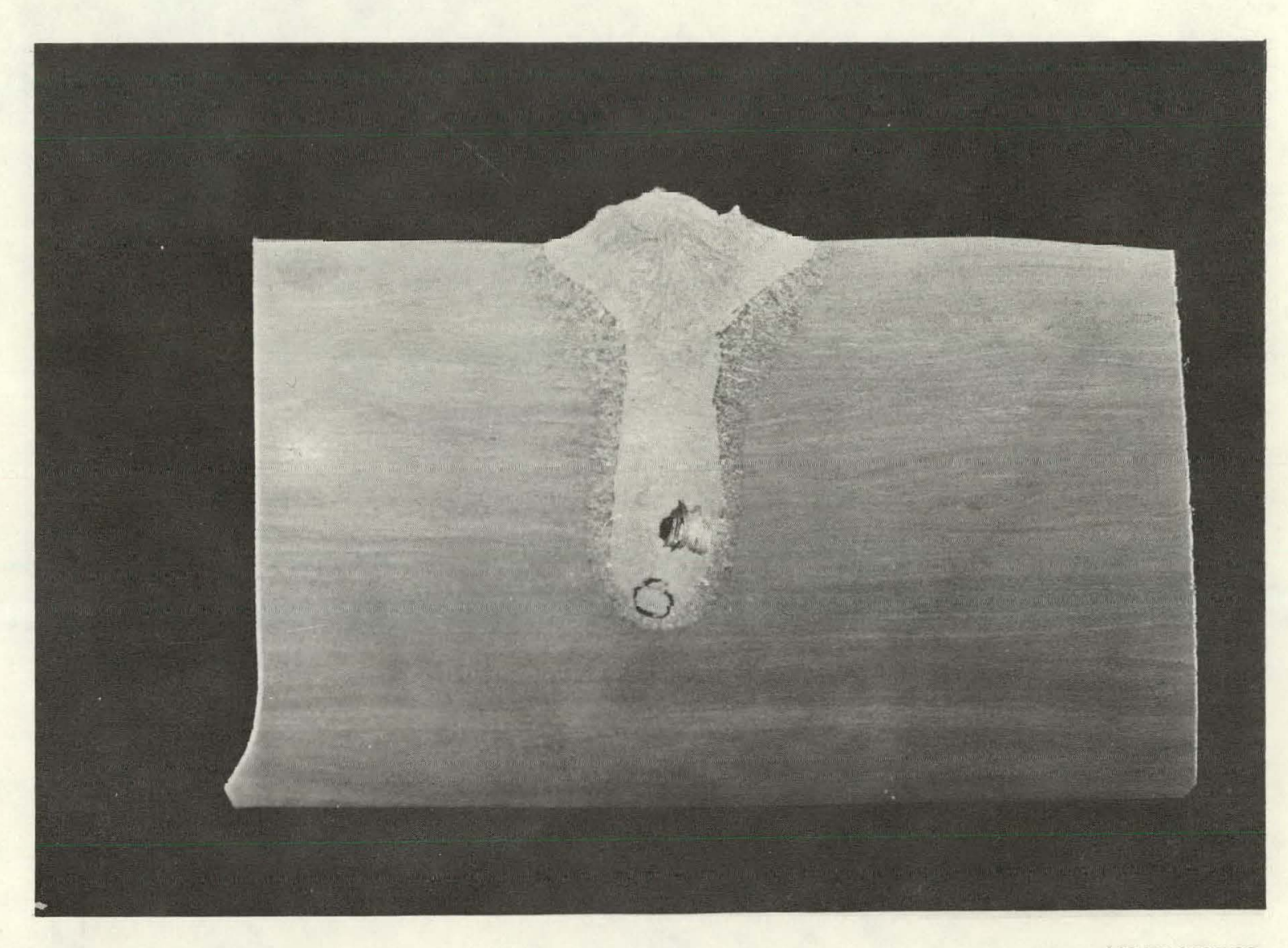

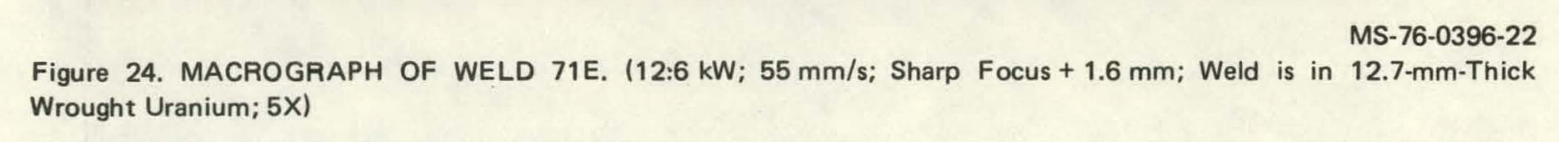
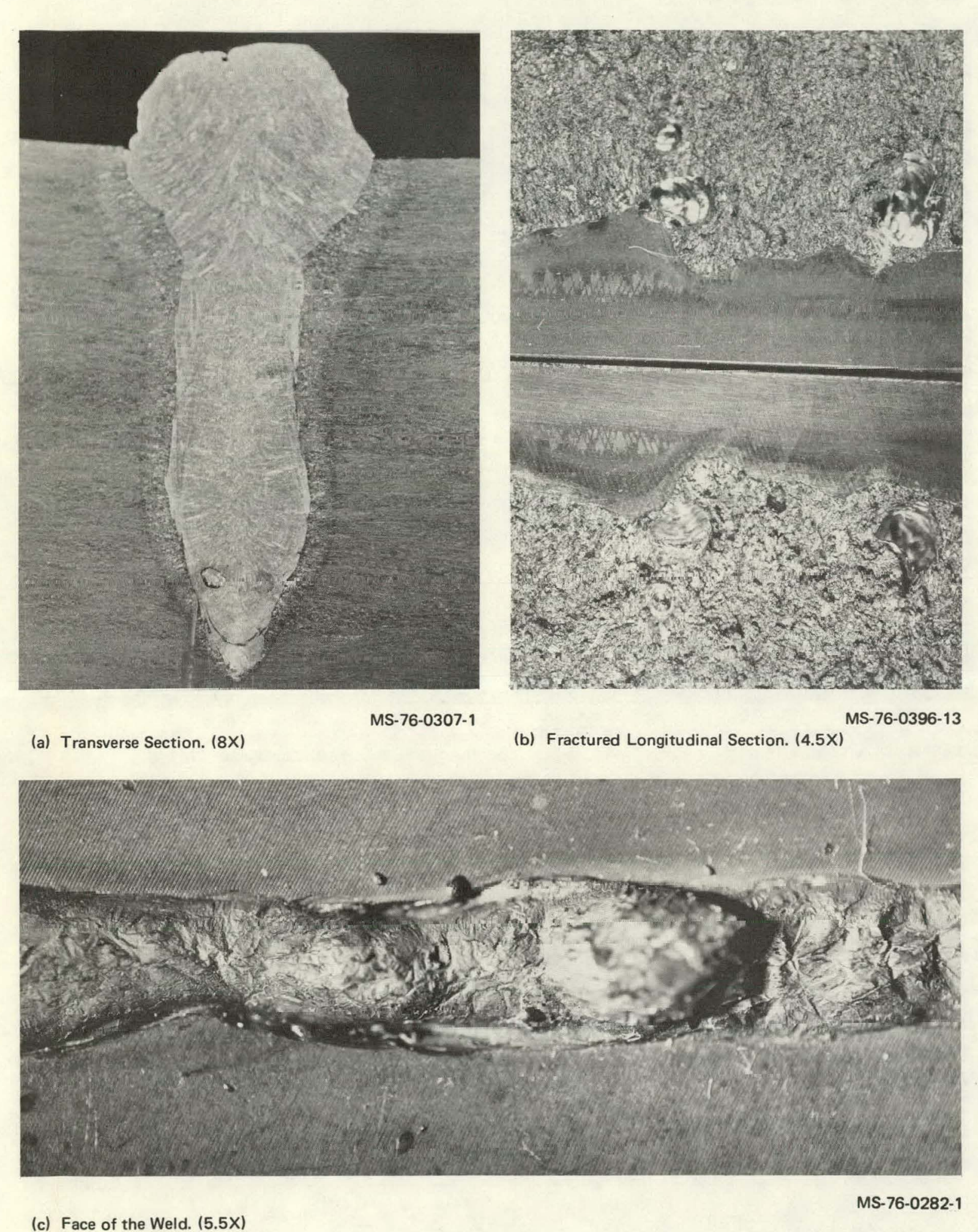

(c) Face of the Weld. (5.5x)

Figure 25. MACROGRAPHS OF WELD 71 C. $112.9 \mathrm{~kW} ; 55 \mathrm{~mm} / \mathrm{s}$; Sharp Focus $+1.6 \mathrm{~mm}$
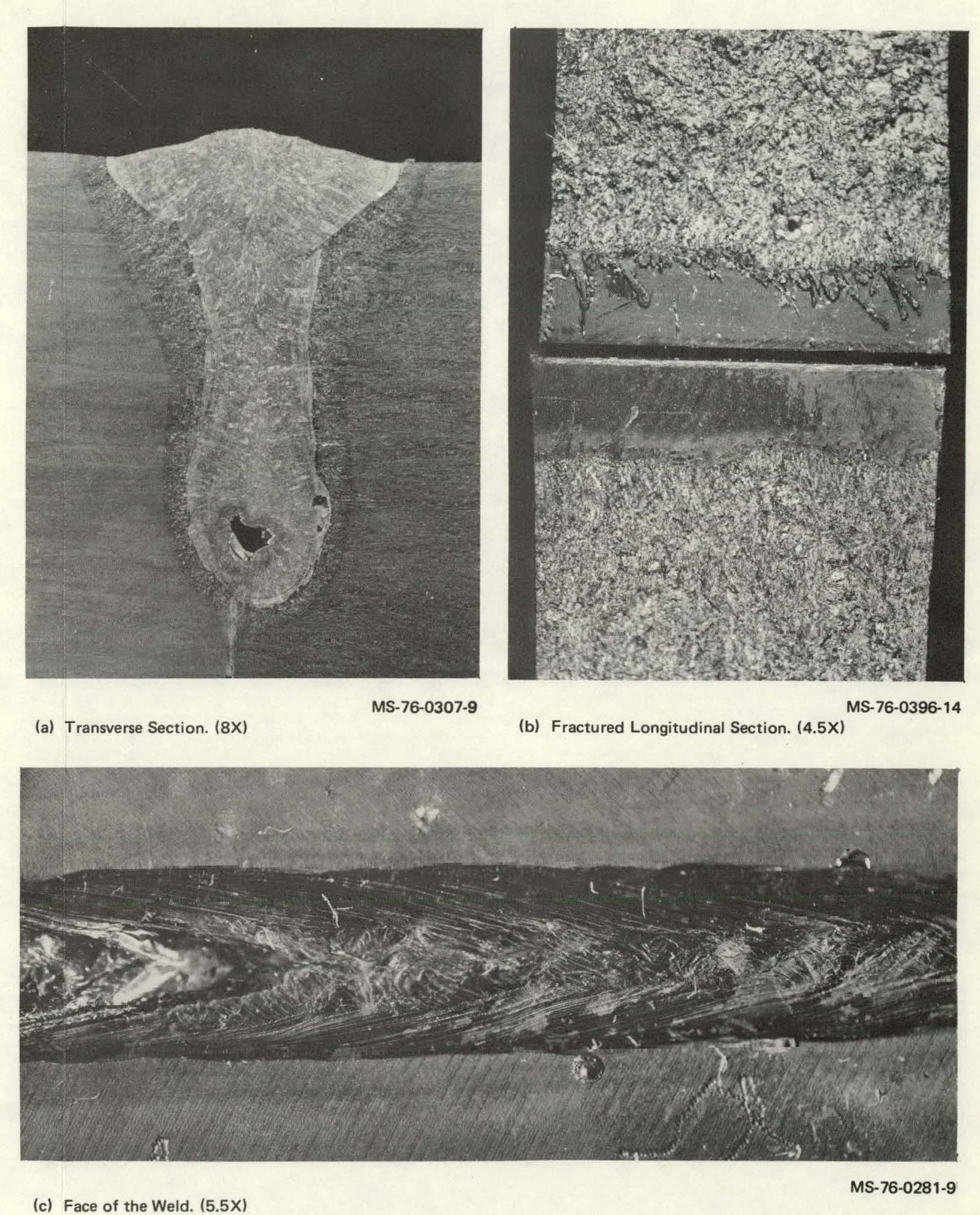

Figure 26. MACROGRAPHS OF WELD 71F. (12.6 kW; $55 \mathrm{~mm} / \mathrm{s}$; Sharp Fouus $+1.6 \mathrm{~mm})$ ) 

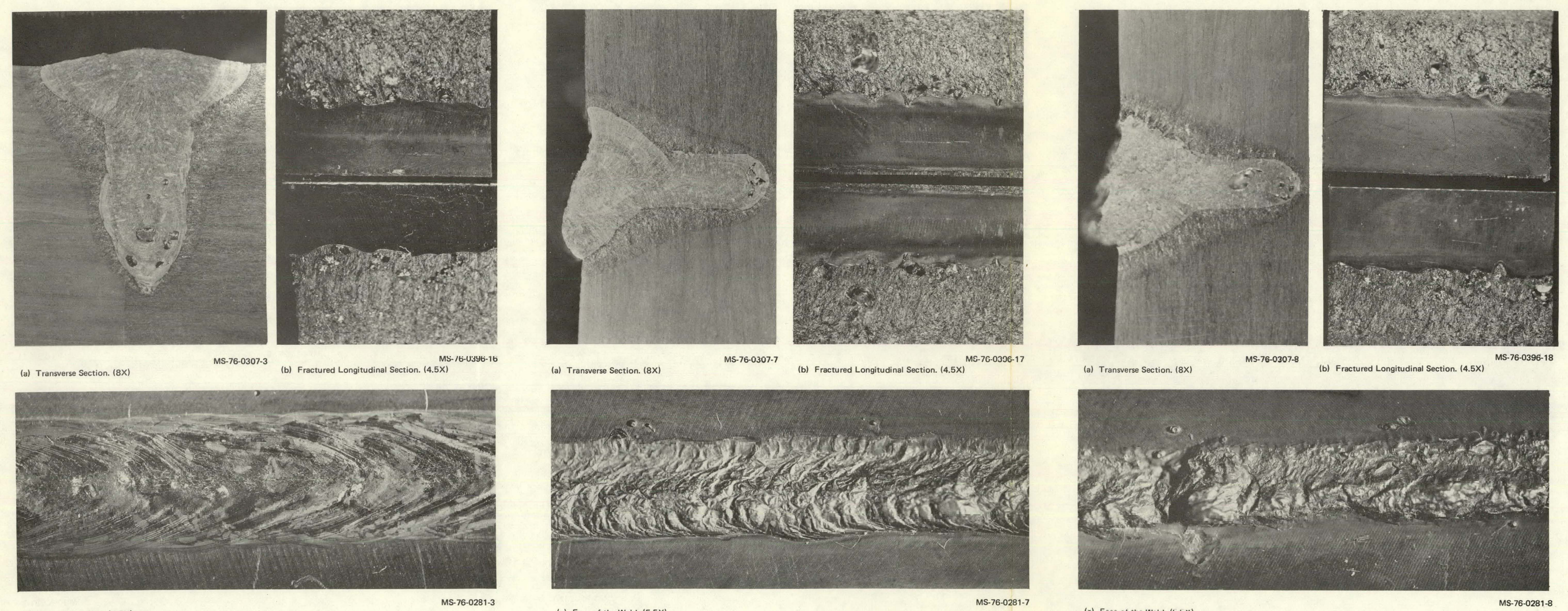

(c) Face of the Weld. (5.5x)

Ms-76-0281-3 (c) Face of the Weld. (5.5x)

Ms-76-0281-.

Figure 27. MACROGRAPHS OF WELD 728.19 .1 kW; $32 \mathrm{~mm} / \mathrm{s}$; Sharp Focus $+1.6 \mathrm{~mm})$

Figure 28. MACROGRAPHS OF WELD 748 . $19.1 \mathrm{~kW}$; $32 \mathrm{~mm} / \mathrm{ss}$ : Sharp Focus)

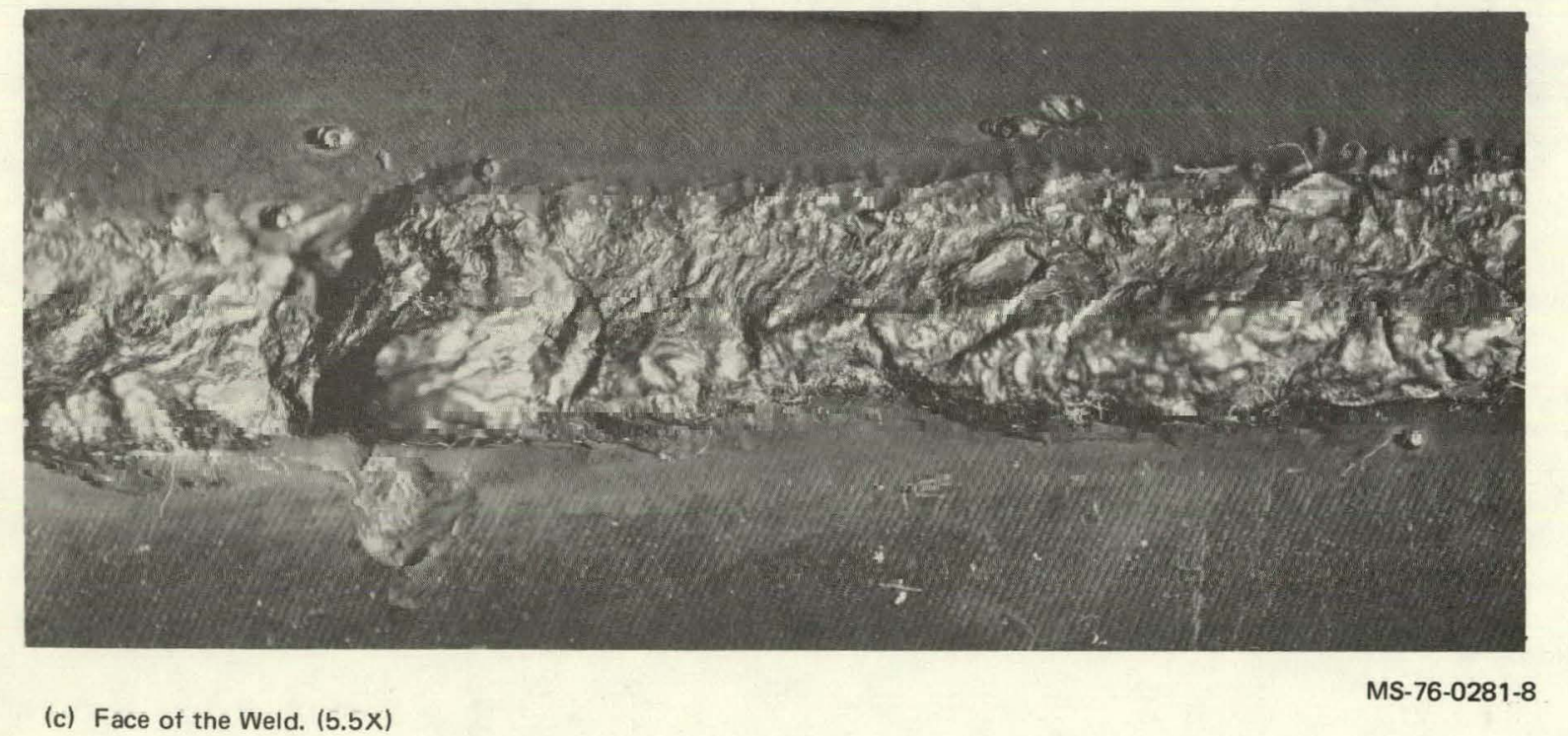

(c) Face of the Weld. (5.5x)

Figure 29. MACROGRAPHS OF WELD $74 C$. $19.1 \mathrm{~kW} ; 32 \mathrm{~mm} / \mathrm{s}$; Sharp Focus 

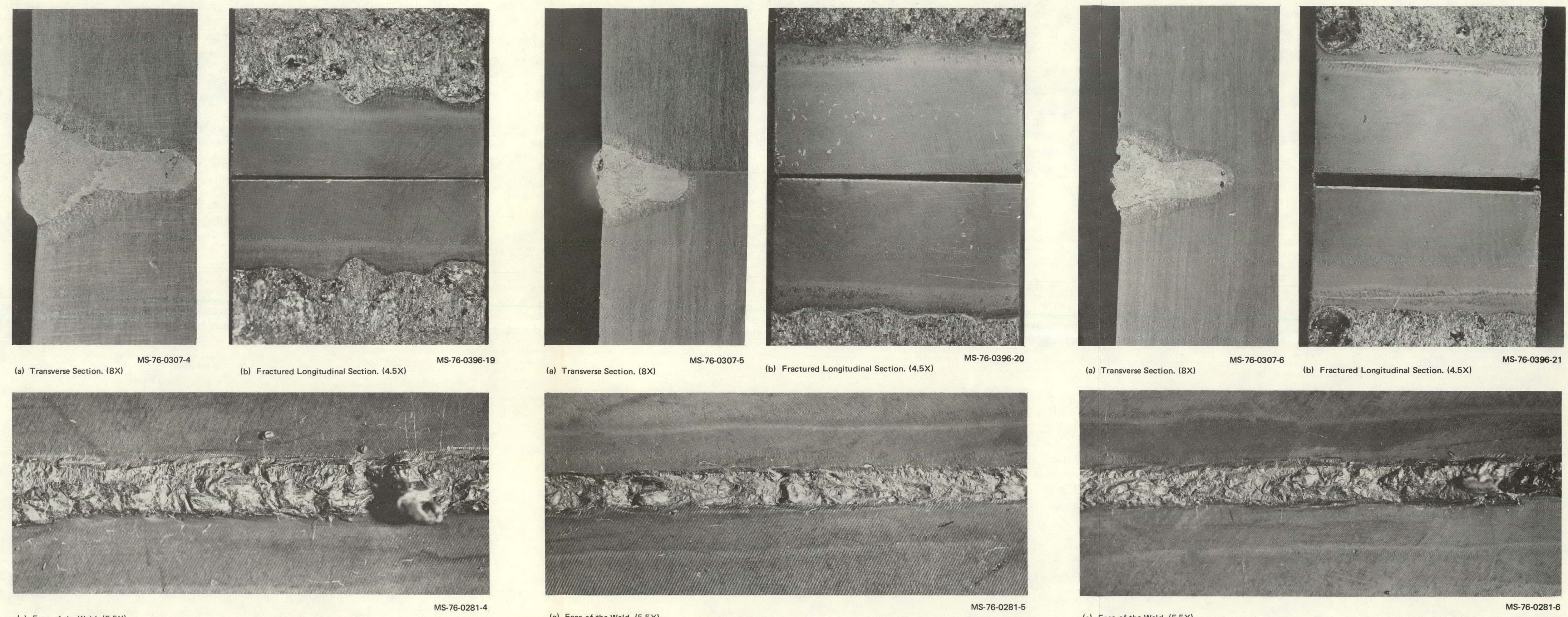

(a) Transverse Section. (88)

$\begin{array}{ll}\text { MS-76-0307-6 } & \text { (b) Fractured Longitudinal Section. (4.5x) }\end{array}$

(c) Face of the Weld. (5.5x

(c) Face of the Weld. (5.5) MS-76-0281-5 Figure 30. MACROGRAPHS OF WELD $74 D .(11.9 \mathrm{~kW} ; 55 \mathrm{~mm} / \mathrm{s}$ : Sharp Focus $+1.6 \mathrm{~mm})$ Figure 31. MACROGRAPHS OF WELD 74E. $17.4 \mathrm{~kW} ; 76 \mathrm{~mm} / \mathrm{s}$; Sharp Focus $+1.6 \mathrm{~mm})$

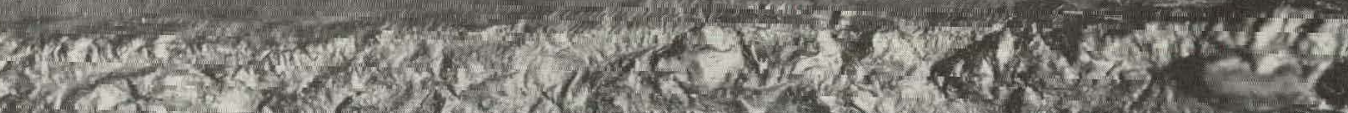

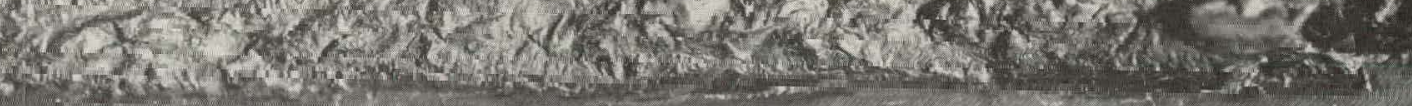

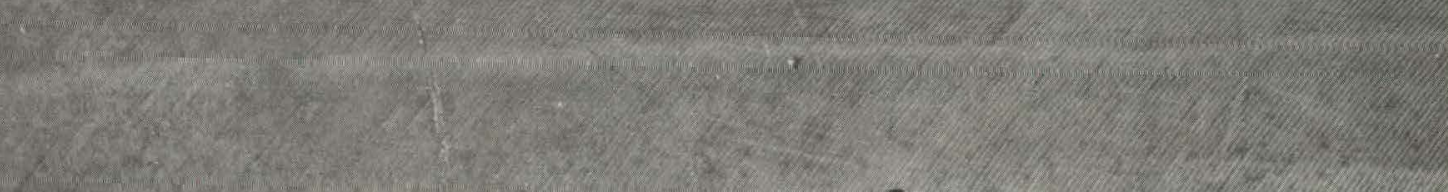


horizontal welds. Poor shielding has caused the poor appearance of the face of these welds and may have contributed to the formation of gross defects. With a trailing gas shield, horizontal welding with the laser process offers much potential in welding uranium and other high-density metals that are practically unweldable in the horizontal position. Welding in this position could simplify and considerably decrease the cost of weld tooling.

At high speed and power, the weld-bead width varied in a cyclical manner (Welds $70 \mathrm{C}$ and $70 D$ are typical). The penetration tended to vary in a like manner in that welds were deeper where the bead became narrow. The cause is not known, but may have been due to cyclical variation in the welding speed. At slow speeds, the welds began to take on the appearance of arc welds. 


\section{Distribution}

EG\&G Idaho - Idaho Falls

Turner, P. W.

Energy Research and Development Administration - Oak Ridge

Hickman, H. D.

Leed, R. E.

Zachry, D. S., Jr

Lawrence Livermore Laboratory

Nelson, W. E.

Los Alamos Scientific Laboratory

Hoyt, H. C.

Oak Ridge Gaseous Diffusion Plant

Stief, S. S.

Wilcox, W. J., Jr

\section{Oak Ridge National Laboratory}

Weir, J. R., Jr

Oak Ridge Y-12 Plant

Armstrong, R. C.

Alvey, H. E.

Bernander, N. K.

Burditt, R. B.

Dodson, W. H.

Dritt, W. S.

Duggan, H. G.

Fraser, R. J.

Gritzner, V. B.

Häèuslèr, K. R.

Jackson, V. C.

Jones, F. W.

Kahl, K. G.

Keith, A.

Kite, H. T.

Martin, W. R./Googin, J. M.
Mason, D. L.

Mills, J.. M., Jr

Phillips, L. R.

Pollock, C. B.

Rhew, J. E:

Schreyer, J. M.

Smith, H. Fi, Jr

Smith, R. D.

Stephens, A. E.

Stoner, H. H.

Tewes, W. E.

Tilson, F. V.

Townsend, A. B. (35)

Y-12 Central Files (master copy)

$Y-12$ Central Files (route copy)

$Y-12$ Central Files (Y-12RC)

$Y-12$ Central Files (5)

Paducah Gaseous Diffusion Plant

Bewley, H. D.

Union Carbide Corporation-Parma

Research Center

Chambers, W. E.

Union Carbide Corporation - New York

Winters, Charles

University of Tennessee-College

of Engineering

Stansbury, E. E.

In addition, this report is distributed in accordance with the category UC-38, Engineering and Equipment, as given in the USERDA Standard Distribution Lists for Unclassified Scientific and Technical Reports, TID-4500. 